\title{
Micro-kinetics of $\mathrm{NO}_{x}$ storage and reduction with $\mathrm{H}_{2} / \mathrm{CO} / \mathrm{C}_{3} \mathrm{H}_{6}$ on $\mathrm{Pt} / \mathrm{BaO} / \mathrm{Al}_{2} \mathrm{O}_{3}$ monolith catalysts
}

\author{
Arun S Kota, Dan Luss, Vemuri Balakotaiah * \\ Dept. of Chemical \& Biomolecular Engineering, \\ University of Houston, Houston, TX 77204
}

September 15, 2014

\begin{abstract}
Isothermal steady state $\mathrm{NO}_{x}$ storage and reduction on $\mathrm{Pt} / \mathrm{BaO} / \mathrm{Al}_{2} \mathrm{O}_{3}$ by $\mathrm{H}_{2} / \mathrm{CO} /-$ $\mathrm{C}_{3} \mathrm{H}_{6}$ reactant mixtures is studied using, $1+1$ dimensional two-phase model that accounts for washcoat diffusional limitations. It predicts the storage and reduction performance over a wide range of inlet feed concentrations and temperatures. A major limitation of global kinetic models is not being able to predict accurately the performance of the catalyst with changing feed composition. Micro-kinetic models elucidating the role of individual reductants can account for such variations. The temperature dependence of the rate constants has been quantified so that the surface chemistry is consistent with experimental observations. Inclusion of washcoat diffusion enables the model to accurately predict the $\mathrm{NO}_{x}$ conversion and scale-up performance of the catalyst over a wide temperature range. The sensitivity of the estimated kinetic parameters to the effective diffusivities in the washcoat is analyzed. Results indicate that the estimated micro-kinetic parameters are influenced by the washcoat pore structure as well as the properties of the catalytic and storage components.
\end{abstract}

\footnotetext{
${ }^{*}$ Corresponding Author: V. Balakotaiah, Email: bala@uh.edu, Tel: 713-743-4318
} 


\section{Introduction}

Reducing $\mathrm{NO}_{x}$ emissions from diesel engines remains a challenge due to the high air to fuel ratio in the engine feed. The excessive oxygen renders the conventional three-way catalysts inefficient in reducing $\mathrm{NO}_{x}$ in the lean-burn engine exhaust. $\mathrm{NO}_{x}$ storage and reduction has evolved to be a promising technology in reducing $\mathrm{NO}_{x}$ under lean conditions. It consists of treating $\mathrm{NO}_{x}$ over a bifunctional catalyst to form $\mathrm{N}_{2}$ and $\mathrm{H}_{2} \mathrm{O}$. The catalyst is composed of precious metals, storage and support components. A typical $\mathrm{NO}_{x}$ storage and reduction (NSR) catalyst contains precious metals such as $\mathrm{Pt} / \mathrm{Pd} / \mathrm{Rh}$ to enhance the uptake of $\mathrm{NO}_{x}$ and facilitate the oxidation/reduction processes. $\mathrm{NO}_{x}$ is adsorbed onto the storage materials comprising oxides, carbonates and hydroxides of alkaline earth metals such as Ba, $\mathrm{Mg}$, Ca or on alkali metals such as K, Cs etc. The most widely studied formulation of NSR catalyst is $\mathrm{Pt} / \mathrm{BaO} / \mathrm{Al}_{2} \mathrm{O}_{3}$.

Various groups have confirmed the existence of several underlying pathways in the NSR, which include oxidation of $\mathrm{NO}$ to $\mathrm{NO}_{2}$, $\mathrm{NO}$ conversion to $\mathrm{N}_{2} \mathrm{O}$ and $\mathrm{N}_{2}$, formation of $\mathrm{NH}_{3}$, reaction of $\mathrm{NH}_{3}$ with $\mathrm{NO}_{x}$ to form $\mathrm{N}_{2}$ and $\mathrm{H}_{2} \mathrm{O}$ etc. A general consensus is that oxidation of $\mathrm{NO}$ to $\mathrm{NO}_{2}$ over the precious metal is an essential precursor to $\mathrm{NO}_{x}$ storage $[1,2,3]$ and that $\mathrm{NO}_{2}$ is subsequently stored on the trapping material in the form of nitrites/nitrates. Various factors affect the stability of nitrates and in turn influence the $\mathrm{NO}_{x}$ conversion performance. It has been suggested that the stability of the nitrates is increased by the presence of oxygen [4], which otherwise are decomposed resulting in the release of $\mathrm{NO}_{x}$. The presence of carbon oxides and water in the vehicular exhaust complicates the catalytic chemistry in the NSR catalyst [5]. They also affect the stability of the surface nitrates, as $\mathrm{CO}_{2}$ can compete for the storage sites to form carbonates and thus negatively impacting the performance [6] while $\mathrm{H}_{2} \mathrm{O}$ can either enhance or diminish the deNO $\mathrm{N}_{x}$ efficiency of the NSR catalyst [7].

The main products of the stored $\mathrm{NO}_{x}$ regeneration are $\mathrm{NH}_{3}, \mathrm{~N}_{2}, \mathrm{~N}_{2} \mathrm{O}, \mathrm{H}_{2} \mathrm{O}$ and $\mathrm{CO}_{2}$. $\mathrm{NH}_{3}$ is an essential intermediate which reacts with stored $\mathrm{NO}_{x} . \mathrm{NH}_{3}$ is produced when $\mathrm{H}_{2}$ is used as the sole reductant and also when $\mathrm{CO}$ is the reductant in the presence of $\mathrm{H}_{2} \mathrm{O}$, either 
through isocyanate intermediates or through water-gas shift mechanism. Precious metals play a prominant role during $\mathrm{NO}_{x}$ reduction. The $\mathrm{Pt} / \mathrm{BaO}$ interface enables reverse spillover of the $\mathrm{NO}_{x}$ onto the $\mathrm{Pt}$ and is subsequently reduced by the $\mathrm{H}_{2}, \mathrm{CO}$ or $\mathrm{HC}$ (hydrocarbon; $\mathrm{C}_{3} \mathrm{H}_{6}$ in the current study) species. Several studies indicate that $\mathrm{H}_{2}$ is a better reductant compared to $\mathrm{CO}$ and $\mathrm{C}_{3} \mathrm{H}_{6}$, while a precious metal is necessary to activate $\mathrm{H}_{2}$, $\mathrm{CO}$ can be active even on $\mathrm{BaO} / \mathrm{Al}_{2} \mathrm{O}_{3}[8]$.

The motivation to investigate the performance of the NSR with mixed reductants arises because real exhaust gas is comprised of various species such as $\mathrm{H}_{2}, \mathrm{CO}, \mathrm{HC}, \mathrm{CO}_{2}, \mathrm{H}_{2} \mathrm{O}, \mathrm{NO}_{x}$, $\mathrm{NH}_{3}, \mathrm{O}_{2}, \mathrm{~N}_{2}, \mathrm{~N}_{2} \mathrm{O}$ etc. Such complex mixture can influence the optimum operation of the NSR and the SCR catalysts. The main objective of this work is to construct a micro-kinetic model that elucidates the complexities introduced by the combined feed of $\mathrm{H}_{2} / \mathrm{CO} / \mathrm{C}_{3} \mathrm{H}_{6}$. We also aim to provide a wider understanding of the influence that individual reductants exert on the $\operatorname{deNO}_{x}$ activity of the catalysts. To realize this objective we have initially developed a kinetic model for each individual reductant. We then use these models to predict the isothermal NSR performance under various operating conditions. We present the approach towards a reaction mechanism that is corroborated by several UHV and flow reactor investigations. The models are used to fine tune the extracted parameters and test their consistency with observations of prior experimental studies. In the present work, we focus on the $\mathrm{NO}_{x}$ storage and reduction on $\mathrm{Pt} / \mathrm{BaO} / \mathrm{Al}_{2} \mathrm{O}_{3}$ in the presence of $\mathrm{H}_{2} / \mathrm{CO} / \mathrm{C}_{3} \mathrm{H}_{6}$.

\section{Model development}

Several models describe the $\mathrm{NO}_{x}$ storage and reduction processes. Global kinetic schemes have been proposed by Hepburn et al. [9], Olsson et al. [10], and Tuttlies et al. [11] based on the shrinking core model. Scholz et al. [12] developed a global reaction kinetic model based on multiple storage sites. Bhatia et al. [13] proposed a micro-kinetic scheme for NO oxidation on Pt and a global kinetic model [14] for both $\mathrm{NO}_{x}$ storage and reduction that 
is based on the NO oxidation model. They considered two types of $\mathrm{NO}_{x}$ storage sites in the global model named 'fast' and 'slow' sites based on their proximity to the Pt. Olsson et al. [15] presented a detailed model of $\mathrm{NO}_{x}$ storage and reduction over a $\mathrm{Pt} / \mathrm{BaO} / \mathrm{Al}_{2} \mathrm{O}_{3}$ catalyst. Earlier research studies focused exclusively on the individual stages of the NSR such as NO oxidation, or nitrate formation, or the effect of specific reductants on the $\mathrm{NO}_{x}$ release during the regeneration. We attempt to develop a wider understanding of the NSR in the presence of feed consisting of $\mathrm{H}_{2} / \mathrm{CO} / \mathrm{C}_{3} \mathrm{H}_{6}$ by a detailed model that encompasses all the essential stages. The $\mathrm{Pt} / \mathrm{BaO} / \mathrm{Al}_{2} \mathrm{O}_{3}$ catalyst and monolith properties used in this work are listed in Appendices A1 and A2.

\subsection{Species balance equations}

Steady state $1+1$ dimensional two phase model is used to simulate the storage and reduction of $\mathrm{NO}_{x}$ in a single monolith channel. The model incorporates washcoat diffusional limitations. The basic assumptions are a) fully developed laminar flow; b) axial dispersion is negligible compared to convection; c) physical properties are independent of the species concentration; d) concentrations are low so that heat effects can be neglected and the system can be treated as isothermal; e) pressure drop in the channel is negligible; $\mathrm{f}$ ) the reaction mixture is dilute so that gas expansion effects can be neglected. The balance equations are, Species balance in the channel:

$$
\frac{\partial X_{j m}}{\partial t}=-\bar{u} \frac{\partial X_{j m}}{\partial z}-\frac{k_{c}(j, z)}{R_{\Omega}}\left(X_{j m}-X_{j s}\right)
$$

where $X_{j m}$ and $X_{j s}$ are the mole fractions of species $j$ in the bulk fluid and at fluid-washcoat interface respectively, $\bar{u}$ is the average velocity, $k_{c}(j, z)=D_{m, j} S h_{e}(z) / 4 R_{\Omega}$ the position dependent mass transfer coefficient accounts for the transverse gradients in the gas phase, $R_{\Omega}$ is the channel hydraulic radius, $D_{m, j}$ is the gas phase diffusivity of species $j$ in the bulk fluid, $S h_{e}(z)$ is the position dependent external Sherwood number [16]. The gas phase 
diffusivities calculated using Lennard--Jones potentials are reported in Appendix A2.

Species balance in the washcoat:

$$
\varepsilon_{w c} \frac{\partial X_{j w c}}{\partial t}=D_{e w c} \frac{\partial^{2} X_{j w c}}{\partial y^{2}}+\frac{1}{C_{T m}}\left(\sum_{r=1}^{M_{g}} \widehat{\nu}_{j r} R_{r}^{S}\left(\underline{X}_{w c}, \underline{\theta}_{S}\right)+\sum_{r=1}^{M_{g}} \widehat{\nu}_{j r}^{*} R_{r}^{Y}\left(\underline{X}_{w c}, \underline{\theta}_{Y}\right)\right)
$$

here, $X_{j w c}$ is the mole fraction of species $j$ in the washcoat, $\varepsilon_{w c}$ is the washcoat porosity, $D_{e w c}$ is the effective species diffusivity inside the washcoat, $C_{T m}$ the total molar concentration, $\left(\underline{X}_{w c}, \underline{\theta}_{S}\right),\left(\underline{X}_{w c}, \underline{\theta}_{Y}\right)$ are the species mole fraction and fractional surface coverage vector on $\mathrm{S}=\mathrm{Pt}$ and $\mathrm{Y}=\mathrm{BaO}, M_{g}$ is the number of gas species, $\widehat{\nu}_{j r}, \widehat{\nu}_{j r}^{*}$ are the stoichiometric coefficients and $R_{r}^{S}\left(\underline{X}_{w c}, \underline{\theta}_{S}\right), R_{r}^{Y}\left(\underline{X}_{w c}, \underline{\theta}_{Y}\right)$ are the reaction rates involving diffusing (gas phase) species on $\mathrm{S}$ and Y sites, respectively. In this work, we assume that only Pt interacts with gas phase species and take the second summation term to be zero.

\section{Adsorbed/Surface species balance:}

$$
\begin{gathered}
C_{S} \frac{\partial \theta_{S j}}{\partial t}=\sum_{r=1}^{M_{s}} \nu_{j l} R_{S l}\left(\underline{X}_{w c}, \underline{\theta}_{S}\right) \\
C_{Y} \frac{\partial \theta_{Y j}}{\partial t}=\sum_{r=1}^{M_{s}} \nu_{j l}^{*} R_{Y l}\left(\underline{X}_{w c}, \underline{\theta}_{S}, \underline{\theta}_{Y}\right),
\end{gathered}
$$

where, $(S=P t, Y=B a O)$ are the total molar concentration of Pt and BaO sites, $R_{l}$ is the rate of reaction that involves the adsorbed species, $\nu_{j l}, \nu_{j l}^{*}$ are the stoichiometric coefficient and $\left(\underline{\theta}_{S}, \underline{\theta}_{Y}\right)$ are the fractional surface coverage vectors for sites of type $S$ and $Y$, respectively.

\section{Initial and Boundary conditions:}

$$
\begin{aligned}
X_{j m}(z, 0) & =0 & & @ t=0 \\
X_{j w c}(y, z, 0) & =0 & & @ t=0 \\
\theta_{j}(y, z, 0) & =0 & & @ t=0
\end{aligned}
$$


$(i i)$

$$
\begin{aligned}
X_{j m}(0, t) & =X_{\text {inlet }}(t) \quad @ z=0 \\
k_{c}(j, z)\left(X_{j m}-X_{j s}\right) & =-D_{e w c} \frac{\partial X_{j w c}}{\partial y} ; X_{j s}=X_{j w c} @ y=0 \\
-D_{e w c} \frac{\partial X_{j w c}}{\partial y} & =0 \quad @ y=\delta_{w c}
\end{aligned}
$$

The transient equations were solved until steady state conditions prevailed. Initial conditions consist of zero initial concentrations and coverages along with simultaneous inflow of species in the feed. Inlet boundary conditions are as prescribed in Eq 8 while flux continuity and zero flux conditions are applied at the fluid-washcoat interface (@y=0) and washcoat-wall interface (@y $=\delta_{w c}$ ), respectively. The balance equations were discretized in the axial direction using upwind scheme for the convection term in Eq 1 and central differencing for the diffusion term in Eq 2. We have considered a total of 81 grid points in the axial direction and 11 in the transverse direction inside the washcoat, and the integration is performed for 11 gas phase species in the channel and in the washcoat, along with 18 surface species in the washcoat. A total of $\sim 27,000$ variables obtained after discretization were then solved using the method of lines approach where the system of ODEs is integrated in time with the corresponding intial conditions using Livermore solver (LSODE).

\subsection{Kinetic model}

Typical diesel engine exhaust consists of $\mathrm{NO}, \mathrm{NO}_{2}, \mathrm{O}_{2}, \mathrm{H}_{2}, \mathrm{CO}, \mathrm{CO}_{2}, \mathrm{HC}, \mathrm{H}_{2} \mathrm{O}$ etc. The presence of various species increases the complexity of analyzing the mechanism of the reactions occurring on the catalyst surface. We present here a micro-kinetic model that captures the main features of isothermal $\mathrm{NO}$ reduction by $\mathrm{H}_{2} / \mathrm{CO} / \mathrm{C}_{3} \mathrm{H}_{6}$ on a $\mathrm{Pt} / \mathrm{BaO} / \mathrm{Al}_{2} \mathrm{O}_{3}$ catalyst (Appendix A3).

The microkinetic model is based on 25 elementary and quasi-elementary steps. It includes two irreversible steps involving $\mathrm{N}_{2}, \mathrm{~N}_{2} \mathrm{O}$ generation. The model follows some of the mechanistic steps described in the literature along with the deviations based on experimental 
findings by various investigations. The approach is consistent with established surface chemistry. We include storage steps following the generally accepted $\mathrm{NO}_{x}$ spill-over mechanism, where $\mathrm{NO}$ is oxidized to $\mathrm{NO}_{2}$ on $\mathrm{Pt}$ and depending on the proximity of $\mathrm{BaO}$ sites, it spills over to the storage sites forming nitrates. The reactions sequence is shown below, where '*' denotes a vacant $\mathrm{Pt}$ site,

$$
\begin{aligned}
\mathrm{NO}+* & \leftrightharpoons \mathrm{NO} * \\
\mathrm{NO} *+* & \leftrightharpoons \mathrm{N} *+\mathrm{O} * \\
\mathrm{NO} *+\mathrm{O} * & \leftrightharpoons \mathrm{NO}_{2} *+* \\
\mathrm{NO}_{2} * & \leftrightharpoons \mathrm{NO}_{2}+* \\
\mathrm{O}_{2}+2 * & \leftrightharpoons 2 \mathrm{O} \\
2 \mathrm{~N} * & \rightarrow \mathrm{N}_{2}+2 * \\
\mathrm{NO} *+\mathrm{N} * & \rightarrow \mathrm{N}_{2} \mathrm{O}+2 * \\
\mathrm{BaO}+3 \mathrm{NO}_{2} * & \leftrightharpoons \mathrm{Ba}\left(\mathrm{NO}_{3}\right)_{2}+\mathrm{NO} *(f, s)
\end{aligned}
$$

Reactions R1-R5 comprise NO oxidation reaction on Pt. It is well known by now that Pt plays a crucial role in oxidizing $\mathrm{NO}$ to $\mathrm{NO}_{2}$, which is an important precursor in the $\mathrm{NO}_{x}$ storage[18]. Medhekar et. al. [22] suggested that Pt assists NO decomposition and that a significant portion of the $\mathrm{NO}_{x}$ storage and nitrates reduction occurs at the $\mathrm{Pt}-\mathrm{BaO}$ interface. There is a significant evidence of $\mathrm{Ba}\left(\mathrm{NO}_{3}\right)_{2}$ formation during the $\mathrm{NO}_{x}$ storage. Steps R1,R3, R4 and R8 are consistent with the generally accepted and experimentally verified stoichiometry of the storage reaction where 1 mole of NO is released for every 3 moles of $\mathrm{NO}_{2}$ consumed,

$$
\mathrm{BaO}+3 \mathrm{NO}_{2} \rightleftharpoons \mathrm{Ba}\left(\mathrm{NO}_{3}\right)_{2}+\mathrm{NO}
$$

Reactions R3 and R8 are consistent with a number of studies that suggest the role of $\mathrm{O}$ 
adatom in the formation of nitrates $[18,23,24,25]$. It is to be noted that $\mathrm{R} 8$ is applicable to both 'fast (f)' and 'slow (s)' storage sites. Though broadly ' $f$ ' and ' $s$ ' sites are categorized based on their proximity to Pt, phenomenologically their functionality differs through the interaction of $\mathrm{BaO}$ with the surface and gas species during the storage process. While $\mathrm{BaO}(f)$ sites close to Pt enable spillover/reverse-spillover of $\mathrm{O}^{*}, \mathrm{NO}^{*}, \mathrm{NO}_{2}$ * species during storage [26], remote $\mathrm{BaO}(s)$ sites carry out direct interaction with the species from gas phase and diffusion through Ba phase thus representing the difference in time scales. As stated earlier, in this work we ignore the direct adsorption of gas phase $\mathrm{NO}_{2}$ or any other species with Ba sites and hence take the second summation term in Eq 2 to be zero.

The reduction of stored $\mathrm{NO}_{x}$ occurs through a Pt catalyzed pathway, forming $\mathrm{NH}_{3}$ as the intermediate which again reacts with $\mathrm{NO}_{x}$ to form $\mathrm{N}_{2}$ and $\mathrm{H}_{2} \mathrm{O}$. Regeneration has been studied by several groups focusing on the effects of type and amount of the reductant, and that of the lean and rich times. Commonly studied reductants are $\mathrm{H}_{2}, \mathrm{CO}, \mathrm{C}_{3} \mathrm{H}_{6}$ and it has been suggested that $\mathrm{H}_{2}$ is a better reductant than $\mathrm{CO}[27,28,29,30]$, especially at low temperatures $\left(\mathrm{T}<250^{\circ} \mathrm{C}\right)$. At high temperatures the performance of $\mathrm{H}_{2}$ and $\mathrm{CO}$ is similar. $\mathrm{H}_{2}$ and $\mathrm{CO}$ are known to be more efficient reductants than $\mathrm{C}_{3} \mathrm{H}_{6}$. We study the kinetic mechanism of the reactions involving $\mathrm{NO}$ and $\mathrm{H}_{2} / \mathrm{CO} / \mathrm{C}_{3} \mathrm{H}_{6}$ and compare the predictions with experimental data and evaluate the key parameters involved in the NSR process. The impact of $\mathrm{H}_{2} \mathrm{O}$ on the $\mathrm{NO}_{x}$ reduction has practical significance because of its presence in the exhaust gas during the combustion. The model accounts for adsorption and desorption of $\mathrm{H}_{2} \mathrm{O}$ and for the inhibiting effect of $\mathrm{H}_{2} \mathrm{O}$ on $\mathrm{NO}$ adsorption, suggested in the literature [32]:

$$
\begin{aligned}
\mathrm{H}_{2}+2 * & \leftrightharpoons 2 \mathrm{H} * \\
\mathrm{H} *+\mathrm{O} * & \leftrightharpoons \mathrm{OH} *+* \\
\mathrm{OH} *+\mathrm{H} * & \leftrightharpoons \mathrm{H}_{2} \mathrm{O} *+* \\
\mathrm{H}_{2} \mathrm{O} * & \leftrightharpoons \mathrm{H}_{2} \mathrm{O}+*
\end{aligned}
$$




$$
\begin{aligned}
N O *+H * & \leftrightharpoons N *+O H * \\
N *+H * & \leftrightharpoons N H *+* \\
N H *+H * & \leftrightharpoons N H_{2} *+* \\
N H_{2} *+H * & \leftrightharpoons N H_{3} *+* \\
N H_{3} * & \leftrightharpoons N H_{3}+*
\end{aligned}
$$

$\mathrm{R} 1, \mathrm{R} 2, \mathrm{R} 9-\mathrm{R} 17$, comprise the overall reaction for $\mathrm{NH}_{3}$ formation. Based on experimental observations by Clayton et al. [31], we propose that $\mathrm{NH}$ is one of the key intermediates in the formation of $\mathrm{N}_{2} \mathrm{O}, \mathrm{N}_{2}$ and $\mathrm{NH}_{3}$. It reacts with the surface isocyanates to form $\mathrm{N}_{2} \mathrm{O}$ and $\mathrm{N}_{2}$, and is easily hydrolyzed by water to form $\mathrm{NH}_{3}$.

$\mathrm{CO}$ is a well known inhibiter on Pt metal catalyst [33]. Studies indicate that NCO is an intermediate in the formation of $\mathrm{N}_{2}$ and $\mathrm{NH}_{3}$ during the regeneration [34, 35]. Szailer et. al. [36] reported significant formation of $\mathrm{NCO}$ species on $\mathrm{Pt} / \mathrm{Al}_{2} \mathrm{O}_{3}$ between $200-400^{\circ} \mathrm{C}$ with a maximum at around $300^{\circ} \mathrm{C}$ The reaction steps are as follows:

$$
\begin{aligned}
\mathrm{CO}+* & \leftrightharpoons \mathrm{CO} * \\
\mathrm{CO} *+\mathrm{O} * & \leftrightharpoons \mathrm{CO}_{2} *+* \\
\mathrm{CO}_{2} * & \leftrightharpoons \mathrm{CO}_{2}+* \\
\mathrm{CO} *+\mathrm{N} * & \leftrightharpoons \mathrm{NCO} *+* \\
\mathrm{NCO} *+\mathrm{H}_{2} \mathrm{O} * & \leftrightharpoons \mathrm{NH}_{2} *+\mathrm{CO}_{2} * \\
\mathrm{BaO}+\mathrm{CO}_{2} * & \leftrightharpoons \mathrm{BaCO}_{3}+*(f, s)
\end{aligned}
$$

Reaction steps R18-R20 comprise CO oxidation reaction, and along with steps R9-R12 represent the water-gas shift reaction. The overall reactions for both $\mathrm{CO}$ oxidation and water-gas shift reactions are:

$$
\mathrm{CO}+\frac{1}{2} \mathrm{O}_{2} \leftrightharpoons \mathrm{CO}_{2} \quad \Delta H=-283 \mathrm{~kJ} / \mathrm{mol}
$$




$$
\mathrm{CO}+\mathrm{H}_{2} \mathrm{O} \rightleftharpoons \mathrm{CO}_{2}+\mathrm{H}_{2} \quad \Delta \mathrm{H}=-41.2 \mathrm{~kJ} / \mathrm{mol}
$$

Reactions $\mathrm{R} 8(f, s)$ and $\mathrm{R} 23(f, s)$ represent the storage of $\mathrm{NO}_{x}$ and $\mathrm{CO}_{2}$ on $\mathrm{BaO}$. These are in line with the various literature studies that suggest the existence of different storage sites $[17,18,19]$. The storage sites considered in this study are those pertaining to the proximity of $\mathrm{BaO}$ to $\mathrm{Pt}$ and to the activity of $\mathrm{BaO}$ towards $\mathrm{NO}_{x}$ and $\mathrm{CO}_{2}$. Lindholm et. al. [20] have presented the direct interaction of $\mathrm{Ba}\left(\mathrm{NO}_{3}\right)_{2}$ and $\mathrm{BaCO}_{3}$ during the storage. In contrast we consider such interaction only through vacant $\mathrm{BaO}$ sites. Such representation keeps the model simple and takes care of all the intermediate steps present during the storage.

Through isotopic labeling experiments Unland [37] suggested the presence of surface NCO species on $\mathrm{Pt} / \mathrm{Al}_{2} \mathrm{O}_{3}$ and described its importance as a reaction intermediate in the formation of $\mathrm{NH}_{3}$ in the presence of $\mathrm{H}_{2} \mathrm{O}$. The following were reported to be the possible reaction routes, along with the water-gas shift reaction, in the formation of $\mathrm{NH}_{3}$ for $\mathrm{NO} / \mathrm{CO} / \mathrm{H}_{2} \mathrm{O}$ reaction system:

$$
\begin{aligned}
\mathrm{NCO} *+2 \mathrm{H}_{2} \mathrm{O} * & \leftrightharpoons \mathrm{NH}_{3} *+\mathrm{CO}_{2} *+\mathrm{OH} * \\
\mathrm{NO} *+5 \mathrm{H} * & \leftrightharpoons \mathrm{NH}_{3} *+\mathrm{H}_{2} \mathrm{O} *
\end{aligned}
$$

The reaction mechanism is consistent with the above steps, R11, R14-R22 represent $\mathrm{NH}_{3}$ formation from NCO, while the other two steps are already described earlier.

Several reaction schemes have been proposed for selective reduction of $\mathrm{NO}_{x}$ using propylene $\left(\mathrm{C}_{3} \mathrm{H}_{6}\right)$. Reduction of $\mathrm{NO}_{x}$ with propene $\left(\mathrm{C}_{3} \mathrm{H}_{6}\right)$ generates complex surface species. To keep the model simple we consider only the following reactions:

$$
\begin{aligned}
\mathrm{C}_{3} \mathrm{H}_{6}+3 * & \leftrightharpoons 3 \mathrm{CH}_{2} * \\
\mathrm{CH}_{2} *+2 \mathrm{O} * & \leftrightharpoons \mathrm{CO} *+\mathrm{H}_{2} \mathrm{O} *+*
\end{aligned}
$$

Reaction R24 and R25 are inline with the experimental observations reported by Kotsifa 
et al. [40], who suggested that the reduction of $\mathrm{NO}$ by $\mathrm{C}_{3} \mathrm{H}_{6}$ always occurs in parallel to propylene oxidation and that the surface $\mathrm{O}$ adatoms, formed either by $\mathrm{NO}$ bond dissociation or dissociative $\mathrm{O}_{2}$ adsorption, is dominant in oxidizing the hydrocarbon intermediates.

Some kinetic parameters were kept constant during the estimation process, using values provided by $\mathrm{Xu}$ et al. [21]. The activation energies for some of the adsorption steps are set to $0 \mathrm{~kJ} / \mathrm{mol}$ assuming them to be non-activated processes. When diffusion in the pores of the washcoat is in the bulk regime, the adsorption rate constants may be expressed as,

$$
k_{j}=S_{0 j} C_{T m} \alpha_{v} \sqrt{\frac{R T}{2 \pi M_{w j}}}
$$

where $S_{0 j}$ is the sticking coefficient of species $j$ at zero coverage, $C_{T m}$ is the total molar concentration of the gas, $R$ is the universal gas constant, $T$ is the absolute temperature, $M_{w j}$ is the molecular weight of the species and $\alpha_{v}$ is the exposed Pt surface area per unit volume of washcoat. When diffusion in the pores of the washcoat is in the Knudsen regime, it is more convenient to express the adsorption rate constant as,

$$
k_{j}=k_{0 j} C_{T m} C_{P t}
$$

where $C_{P t}$ is the concentration of active $\mathrm{Pt}$ sites for unit volume of washcoat. Since $C_{P t}$ and $\alpha_{v}$ are linearly related for a fixed Pt dispersion, the difference between Eqs. (11a) and (11b) is rather small, we have adopted Eq.(11a) in what follows. A conventional Arrhenius relation is used to describe the temperature dependent rate constants for surface reactions,

$$
k_{i}=A_{i} e^{-E_{i} / R T}
$$

where, $k_{i}$ is the rate constant in step $i, A_{i}$ and $E_{i}$ are the corresponding pre-exponential factors and activation energies. The values of the pre-exponential factors and activation energies for all the reactions are listed in Appendix A5. The parameter estimates have been 
obtained by minimizing the residual sum of squares from the experimental and calculated conversions and selectivities. Orthogonal distance regression solver package (ODRPACK) was employed to perform the multi-response nonlinear regression [39]. [Remarks: (i) the 25 step micro-kinetic scheme listed above corresponds to 9 overall independent reactions between 14 species (ii) In general, all the micro-kinetics constants are not independent and need to satisfy the enthalpic and entropic constraints imposed by thermodynamics which is discussed in section 4].

\section{$3 \quad$ Washcoat diffusion coefficients}

An important part of the model is accounting for the washcoat diffusion, specifically how the various species diffusivities are calculated. These values, in turn, influence the values of the kinetic parameters that are estimated from the experimental data. In the literature, various models are available for calculating the effective diffusivities based on the washcoat structure (i.e. micro and macro porosity, pore size distribution, pore connectivity, etc.). However, most of these models do not consider the presence of storage or catalytic materials within the pores of the washcoat. For example, in $\mathrm{Pt} / \mathrm{BaO} / \mathrm{Al}_{2} \mathrm{O}_{3}$ catalysts, the $\mathrm{Pt}$ crystallite size is not uniform and can vary widely (typical values being 3 to $20 \mathrm{~nm}$ depending on the dispersion and/or aging of the catalyst) while the barium particle size varies with the amount of $\mathrm{NO}_{x}$ stored. Both sizes are strongly dependent on the catalyst temperature history. Further, the presence of these active materials influences the pore connectivity and hence the species effective diffusivities profoundly (e.g. crystallite size could be of the same order of magnitude or larger than the diameter of some pores). Further, unlike the case for traditional catalysts, the porosity (as well as tortuosity) in the dual function catalysts such as $\mathrm{Pt} / \mathrm{BaO} / \mathrm{Al}_{2} \mathrm{O}_{3}$ varies with the amount of $\mathrm{NO}_{x}$ stored. Since our focus here is not on the detailed washcoat structure, we use a simpler model for estimating the effective diffusivities. We assume an effective average pore radius $\left(r_{e f f}\right)$ and diffusion in the partially blocked pores 


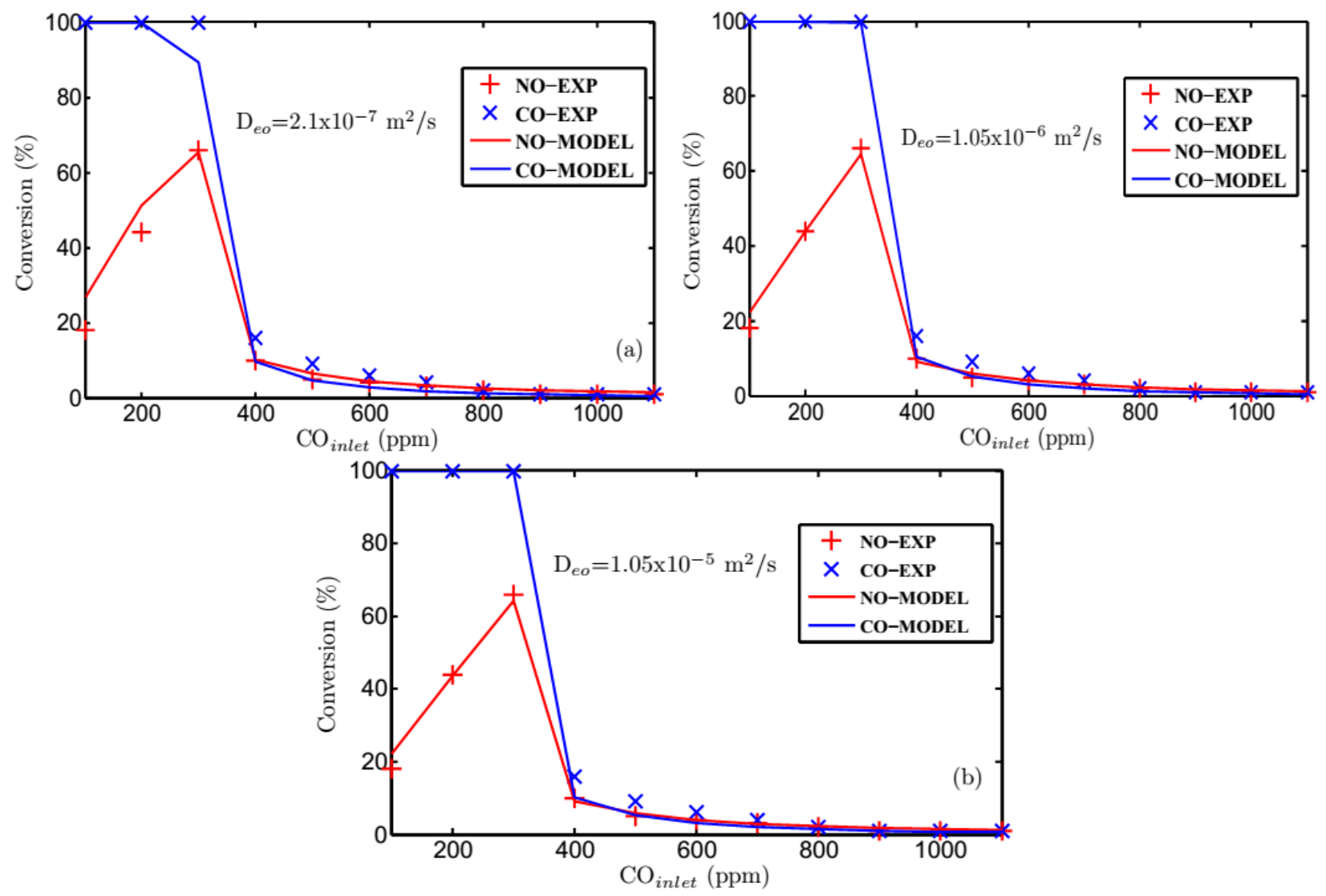

Figure 1: Comparison of experimental and model results for $\mathrm{NO}$ and $\mathrm{CO}$ conversions at different values of $D_{e 0}$ at $270^{\circ} \mathrm{C}$. The feed consists of $\mathrm{NO}(500 \mathrm{ppm})+\mathrm{CO}(15-1200 \mathrm{ppm})$ over $\mathrm{Pt} / \mathrm{BaO} / \mathrm{Al}_{2} \mathrm{O}_{3}$ catalyst.

of the washcoat can be described by a modified form of the Knudsen diffusion formula:

$$
D_{e w c}=\left(\frac{\varepsilon_{w c}}{\tau}\right) 97 r_{e f f} \sqrt{\left(\frac{T_{s}}{M_{w j}}\right)}=D_{e 0} \sqrt{\left(\frac{T_{s}}{T_{r}}\right)\left(\frac{M_{w r}}{M_{w j}}\right)},
$$

where $D_{e 0}=\left(\frac{\varepsilon_{w c}}{\tau}\right) 97 r_{e f f} \sqrt{\left(\frac{T_{r}}{M_{w r}}\right)}$ is the diffusivity at the reference temperature $T_{r}$ and molecular weight $M_{w r}$. It accounts for the changes in porosity, tortuosity and the effective average pore radius $\left(r_{e f f}\right)$. Here, $T_{s}$ is the absolute temperature, and $M_{w r}$ the molecular weight of the species. For the base case, we assume that $D_{e 0} \sim 2.1 \times 10^{-7} \mathrm{~m}^{2} / \mathrm{s}$ at $T_{r}=275^{\circ} \mathrm{C}$ and $M_{w r}$ $=28$ and vary this parameter to study the sensitivity of the estimated kinetic parameters.

Figure 1 shows a comparison between the model predictions and experimental results, 


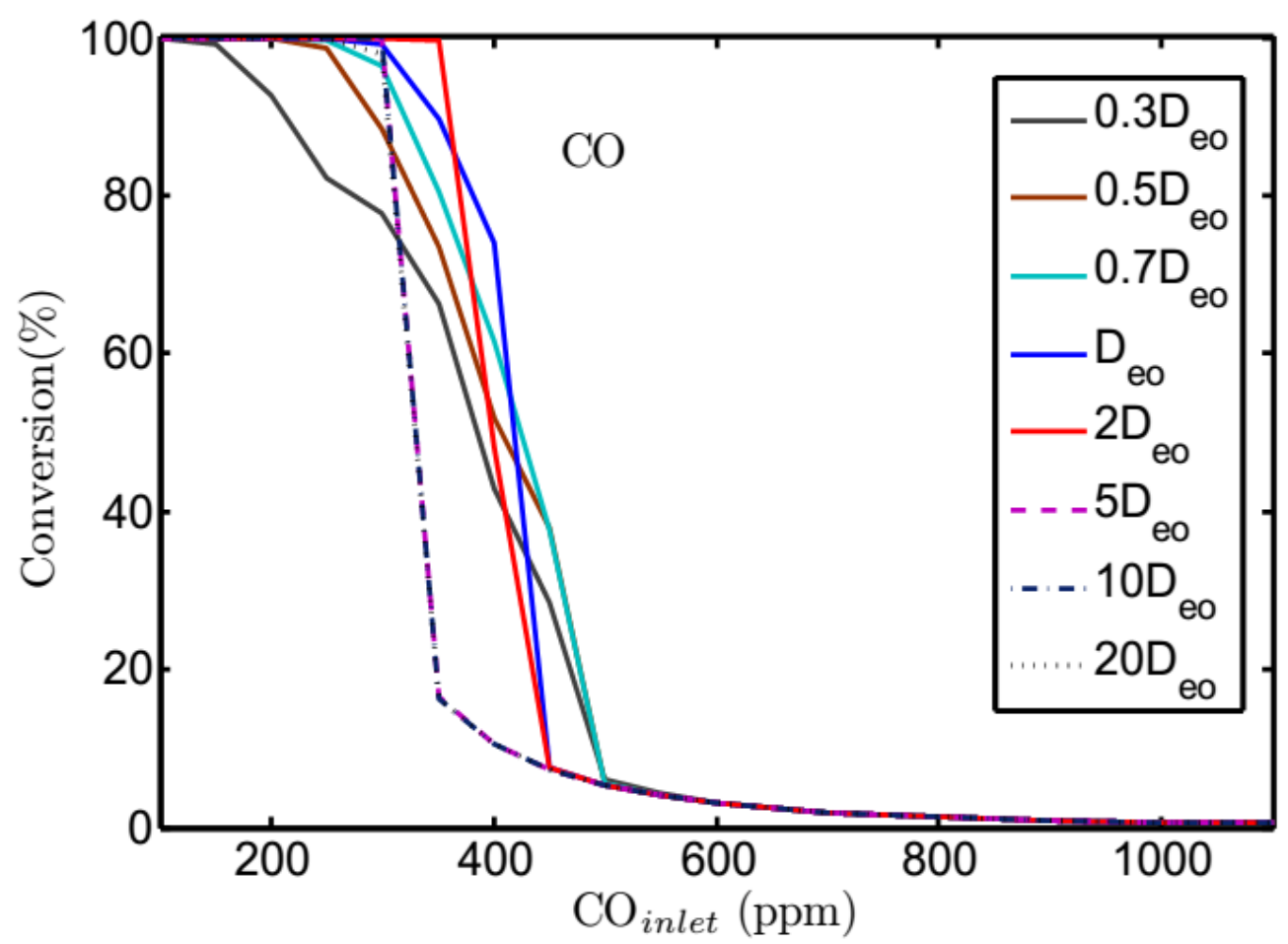

Figure 2: Dependence of CO conversion on the effective diffusivity in the washcoat at $270^{\circ} \mathrm{C}$ with the feed consisting of $\mathrm{NO}(500 \mathrm{ppm})+\mathrm{CO}(15-1200 \mathrm{ppm})$ over the $\mathrm{Pt} / \mathrm{BaO} / \mathrm{Al}_{2} \mathrm{O}_{3}$ catalyst.

while Figure 2 gives the sensitivity of CO conversion to various values of washcoat diffusivity. Using a much lower value for $D_{e o}$ leads to lower than observed CO conversions, while at a sufficiently high $D_{e o}$ value, the conversion (or kinetic parameters) become insensitive. We took the lowest $D_{e o}$ value that gives the closest fit to the experimental data. An important consideration in the estimation of the intrinsic kinetic parameters is the diffusional disguise of the kinetics. The model already accounted for external mass transfer (gas phase diffusion) as well as diffusion in the washcoat. Thus diffusional disguise could exist only in the pore scale. The importance of pore scale diffusional effects on the estimated values of the micro-kinetic parameters can be estimated by comparing the characteristic times. The pore scale diffusion time of NO molecule, defined as $\frac{L_{\mu}^{2}}{D_{\text {ewc }}}$ (where $L_{\mu}$ is the characteristic pore length taken to be $\sim 10$ nanometers.) is estimated to be $10^{-10}$ s with the base value of $D_{e 0}$. While the time constant for adsorption step $\frac{1}{\left(S_{0 N O} \alpha_{v}\left(1-\theta_{v}\right)\left(\frac{R T}{2 \pi M_{w j}}\right)^{0.5}\right)}$ is approximately $10^{-9} \mathrm{~s}$. Based on these 
estimates, it appears that the system is close to the transition region beyond which microkinetics could be disguised by pore scale diffusional effects. Similar comparison between the time constants of adsorption for $\mathrm{CO}, \mathrm{H}_{2}, \mathrm{C}_{3} \mathrm{H}_{6}$ revealed that the kinetic parameters are sensitive to the effective diffusivities of the species in $\mathrm{NO} / \mathrm{CO}$ and $\mathrm{NO} / \mathrm{C}_{3} \mathrm{H}_{6}$ systems. However, such sensitivity was not observed in $\mathrm{NO} / \mathrm{H}_{2}$ system. This is expected because the time constant for $\mathrm{H}_{2}$ adsorption is $\sim 10^{-8} \mathrm{~S}$ which is about two orders of magnitude higher than the diffusion time constant indicating the presence of pore scale kinetic control.

It should be noted that on the scale of washcoat thickness, all the three systems considered $\mathrm{NO} / \mathrm{H}_{2}, \mathrm{NO} / \mathrm{CO}$ and $\mathrm{NO} / \mathrm{C}_{3} \mathrm{H}_{6}$ exhibit washcoat diffusion controlled regime because

the washcoat scale diffusion time constant $\left(\frac{\delta_{w c}^{2}}{D_{e w c}}\right)$ is estimated to be of the order of $\sim 10^{-3} \mathrm{~s}$. Therefore, depending on the temperature and concentration of the reductants, the reaction can occur either within a thin layer of washcoat close to the fluid-washcoat interface or the entire washcoat. For example, Figure 3 shows the NO species concentration inside the washcoat at different temperatures. Due to high reactivity compared to $\mathrm{CO}$ and $\mathrm{C}_{3} \mathrm{H}_{6}$, the reaction of $\mathrm{H}_{2}$ with $\mathrm{NO}$ is limited to a very small region close to the fluid-washcoat interface while that of $\mathrm{CO}$ and $\mathrm{C}_{3} \mathrm{H}_{6}$ is spread across the washcoat thickness. The figure also shows the existence of different regimes in the system from washcoat diffusion controlled to kinetic controlled regime. Clearly, the kinetic parameters are independent of washcoat properties only if the system is in kinetic controlled regime both on the scale of the washcoat and the (micro and macro) pores. The dependence of the micro-kinetic rate constants on pore scale parameters is generally neglected in most literature studies but could be important in high surface area catalysts such as $\mathrm{Pt} / \mathrm{BaO} / \mathrm{Al}_{2} \mathrm{O}_{3}$.

\section{Results and discussion:}

A typical NSR process comprises initial $\mathrm{NO}_{x}$ storage in the form of nitrates followed by reduction. $\mathrm{NO}_{x}$ breakthrough commences when the storage sites are nearly saturated. 

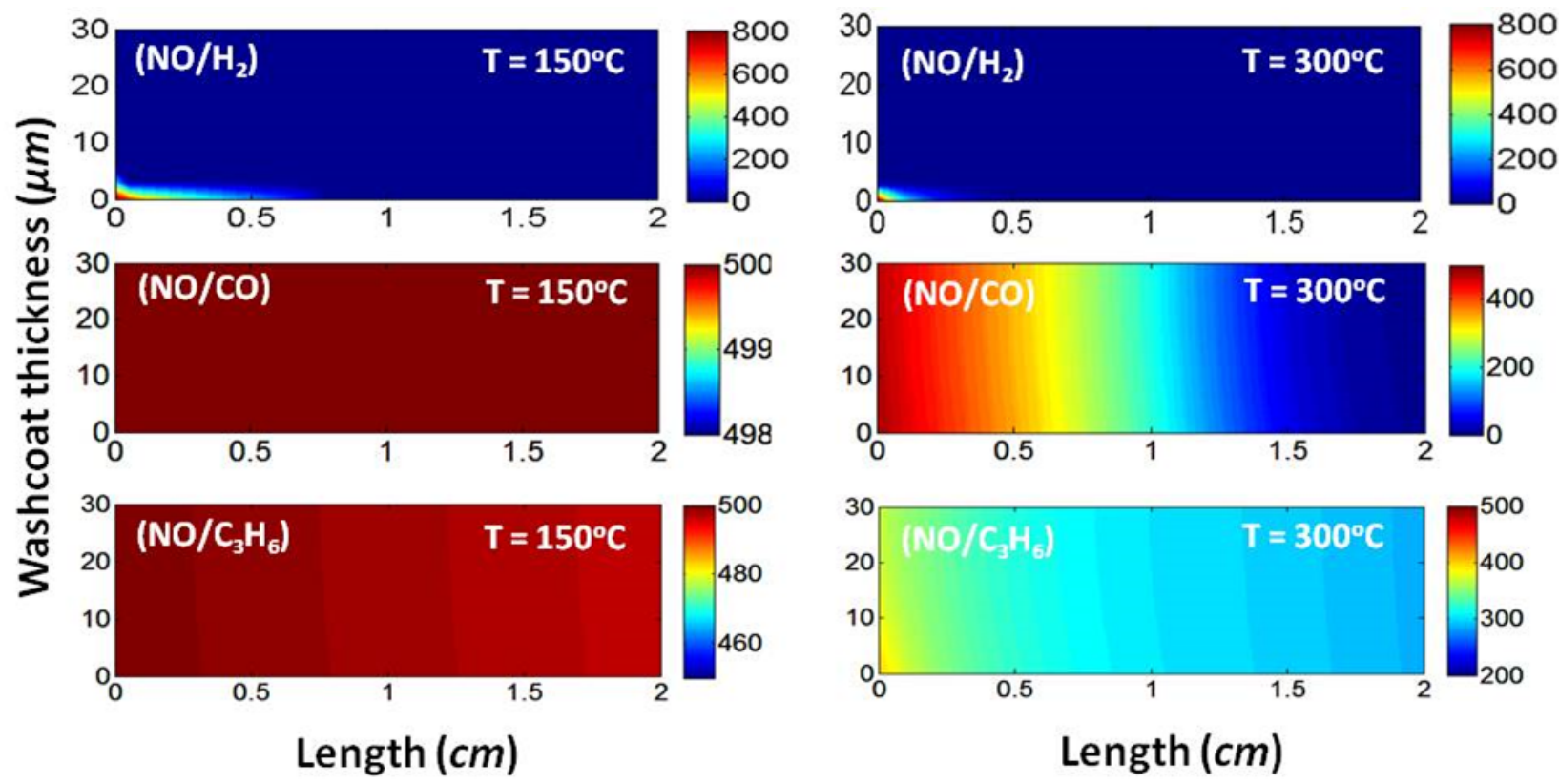

Figure 3: NO concentration inside the washcoat at different temperatures for $\mathrm{NO} / \mathrm{H}_{2}\left(1000 \mathrm{ppm} \mathrm{NO}, 2500 \mathrm{ppm} \mathrm{H} \mathrm{H}_{2}\right)$, NO/CO(500ppm NO, 500ppm CO), NO/C $\mathrm{H}_{6}(500 \mathrm{ppm}$ $\left.\mathrm{NO}, 1000 \mathrm{ppm} \mathrm{C}_{3} \mathrm{H}_{6}, 5 \% \mathrm{O}_{2}\right)$ system; GHSV $=60,000 \mathrm{hr}^{-1}$, Pt loading $=2.2 \mathrm{wt} \%$.

The distribution of products evolved during the regeneration is complex and depends on the temperature and the reductant to $\mathrm{NO}_{x}$ ratio. $\mathrm{NH}_{3}$ is formed as an intermediate during the regeneration with $\mathrm{H}_{2}$ that further reacts with stored $\mathrm{NO}_{x}$ to produce $\mathrm{N}_{2}$ and $\mathrm{H}_{2} \mathrm{O}$. $\mathrm{N}_{2} \mathrm{O}$ and $\mathrm{N}_{2}$ are the primary products of the reduction reactions in the absence of $\mathrm{H}_{2} \mathrm{O}$ using an $\mathrm{NO} / \mathrm{C}_{3} \mathrm{H}_{6}$ feed or $\mathrm{NO} / \mathrm{CO}$ feed, and these pairs are known to produce $\mathrm{NH}_{3}$ in the presence of water. Various studies of the regeneration of stored $\mathrm{NO}_{x}$ reveal that $\mathrm{H}_{2}$ is a better reductant than either $\mathrm{CO}$ or $\mathrm{C}_{3} \mathrm{H}_{6}$. The surface of the catalyst fields various parallel and consecutive pathways and several intermediates during the reduction of $\mathrm{NO}_{x}$ with $\mathrm{H}_{2} / \mathrm{CO} / \mathrm{C}_{3} \mathrm{H}_{6}$ as described in the following sections.

Heats of reactions for the gas phase are used in calculating the heats of surface reactions on the surface as shown below:

$$
\Delta H_{s}=\Delta H_{g}+\left(Q_{2}+Q_{3}-Q_{1}\right)
$$




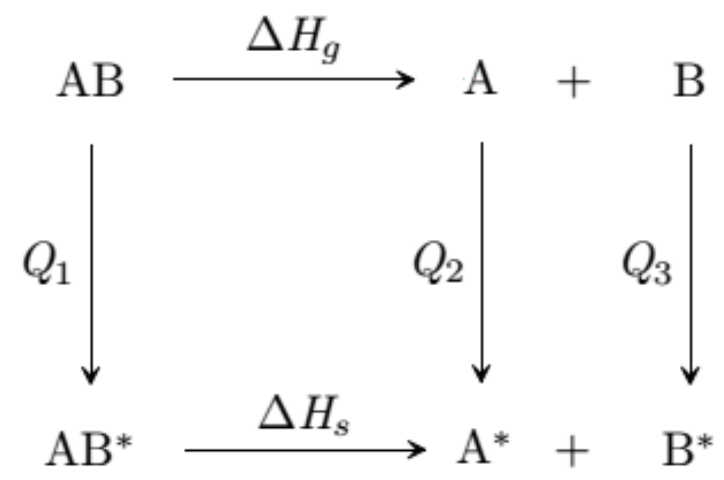

Figure 4: Schematic for surface energetics.

Heats of adsorption for some of the diatomic molecules and monoatomic radicals are adopted from the experimental investigations based on UHV, calorimetric and TPR studies in the literature and are reported in Appendix A4. It can be easily verified that the overall reactions which are considered to be dominant in the system satisfy the enthalpic constraints. Using these values reduces the number of parameters to be estimated. The rest of the activation energy parameters along with the pre-exponentials were estimated and fine tuned using nonlinear orthogonal regression method mentioned earlier [39]. The experimental data obtained from the literature for the following studies correspond to the same catalyst composition, therefore the parameters were estimated for individual systems starting from $\mathrm{NO} / \mathrm{H}_{2}$ followed by $\mathrm{NO} / \mathrm{CO}$ and $\mathrm{NO} / \mathrm{C}_{3} \mathrm{H}_{6}$. The parameters of the prior system were held constant while estimating the parameters for the expanded system.

\section{1 $\mathrm{NO} / \mathrm{H}_{2}$ reaction system:}

The conversion/selectivity data for $\mathrm{NO}-\mathrm{H}_{2}$ reaction performed under isothermal conditions is obtained from the work of $\mathrm{Xu}$ et al.[19] over a range of temperatures and $\mathrm{NO} / \mathrm{H}_{2}$ ratios. All the data involve steady state measurements. The feed gas consists of $1000 \mathrm{ppm}$ $\mathrm{NO}$ and variable amounts of $\mathrm{H}_{2}$ in the absence of $\mathrm{O}_{2}$. The properties of the catalyst used in simulations are given in Appendix A1 and A3. 
NO oxidation and storage steps are the first set of reversible reactions in the kinetic model. There is a general consesus that $\mathrm{NO}$ is first oxidized to $\mathrm{NO}_{2}$ which then is stored as nitrites/nitrates. Some authors argued that the initial step is nitrite formation which are later oxidized by $\mathrm{NO}_{2}$ to nitrates [2]. Other authors argued that nitrates form by direct uptake of $\mathrm{NO}_{2}$ on $\mathrm{BaO}$ [39].

Formation of $\mathrm{NO}_{2}$ and its reversible spill-over onto the barium sites has been highlighted during the storage in many other studies [15]. Taking this into account and to maintain simplicity we have considered $R 8(f, s)$ as the only set of steps representing the nitrate formation. Such interaction with the storage material was not considered by Xu et al. [21]. This also is consistent with the generally established notion that the presence of Pt facilitates the storage
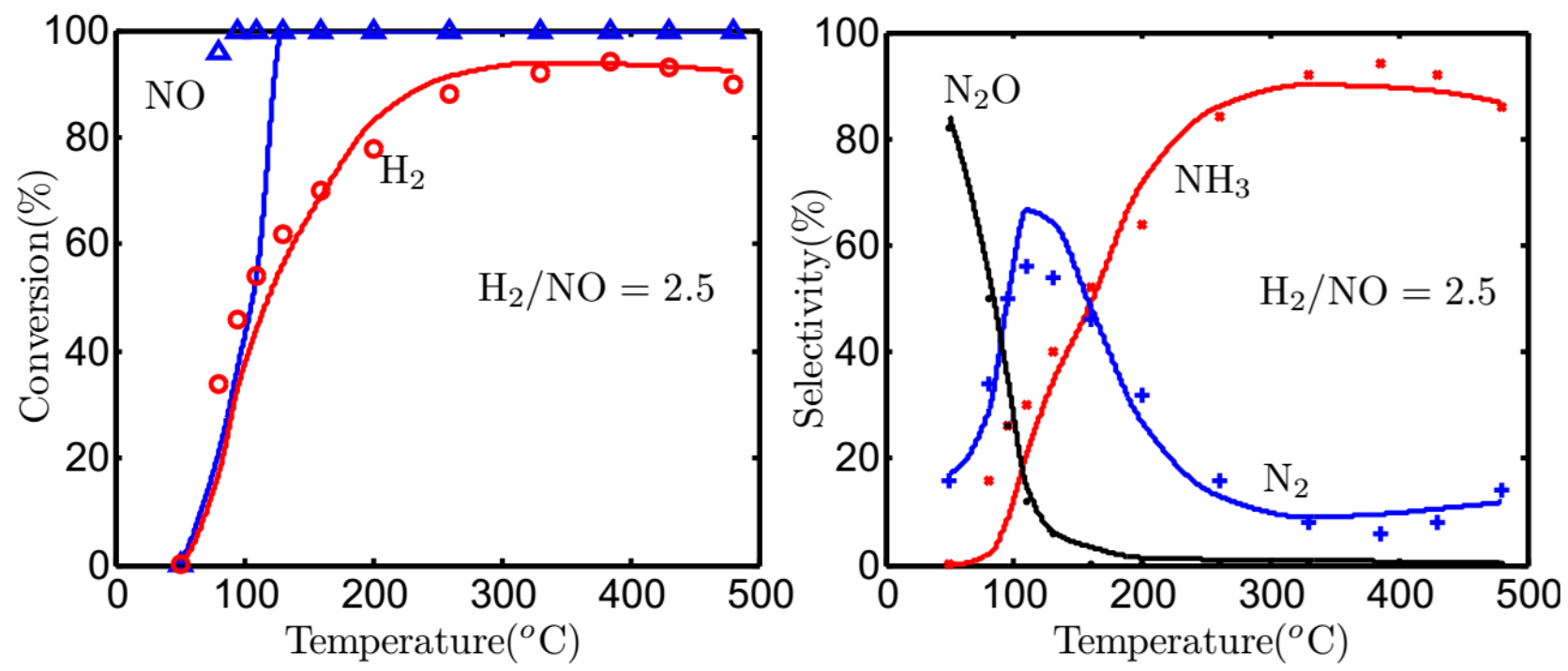

Figure 5: Data fit obtained for the parameter estimation; $\mathrm{NO}, \mathrm{H}_{2}$ conversions for $\mathrm{H}_{2} / \mathrm{NO}=$ 2.5 at different temperatures. Feed: 1000ppm NO, $2500 \mathrm{ppm} \mathrm{H}_{2}, \mathrm{GHSV}=60,000 \mathrm{hr}^{-1}$.

process. The surface reactions and their energetics in the $\mathrm{NO}-\mathrm{H}_{2}$ reaction system is sensitive to the catalyst surface structure and the coverages of NO, N, H species. Figure 5 shows the data used for parameter estimation. $\mathrm{NO}$ and $\mathrm{H}_{2}$ conversions sharply increased in the low temperature $\left(50-75^{\circ} \mathrm{C}\right)$ range. The formation of $\mathrm{N}_{2} \mathrm{O}$ and $\mathrm{NH}_{3}$ are strongly affected by the ratio of $\mathrm{NO} / \mathrm{H}_{2}$ and temperature. Both the experimental and modeling results show that at 
low temperatures $\left(<150^{\circ} \mathrm{C}\right) \mathrm{N}_{2} \mathrm{O}$ is the major product. The formation of $\mathrm{N}_{2} \mathrm{O}$ is described by the following global reaction:

$$
\mathrm{NO}+0.5 \mathrm{H}_{2} \rightarrow 0.5 \mathrm{~N}_{2} \mathrm{O}+0.5 \mathrm{H}_{2} \mathrm{O} \quad \Delta \mathrm{H}=-170 \mathrm{~kJ} / \mathrm{mol}
$$

Figure 6 describes the model prediction for $\mathrm{NO} / \mathrm{H}_{2}$ system. Several mechanistic studies in the literature have indicated a higher selectivity to $\mathrm{N}_{2} \mathrm{O}$ formation at lower temperatures compared to $\mathrm{N}_{2}$ and $\mathrm{NH}_{3}$ [41]. The reaction route for the formation of $\mathrm{N}_{2} \mathrm{O}$ is still a matter of debate. Some authors proposed a combination of adsorbed NO and N species [41] while others have proposed the reaction between two adsorbed NO species, still others have suggested the role of adsorbed $\mathrm{NH}_{x}$ species in the formation of $\mathrm{N}_{2} \mathrm{O}$. In the present work we focus on two important routes with the assistance of the experimental results published in the literature.

The following are the two routes considered in this study for $\mathrm{N}_{2} \mathrm{O}$ formation:

$$
\begin{gathered}
\mathrm{NO} *+\mathrm{N} * \rightarrow \mathrm{N}_{2} \mathrm{O}+2 * \\
\mathrm{NO} *+\mathrm{NH} * \rightarrow \mathrm{N}_{2} \mathrm{O}+\mathrm{OH} *+*
\end{gathered}
$$

$\mathrm{N}^{*}$ could be a product of $\mathrm{NO}^{*}$ dissociation to $\mathrm{N}^{*}$ and $\mathrm{O}^{*}$, or $\mathrm{H}^{*}$ assisted $\mathrm{NO}^{*}$ decomposition to form $\mathrm{N}^{*}$ and $\mathrm{OH}^{*}$ which also has a parallel route forming surface $\mathrm{NH}^{*}$ species. Examining

the kinetic parameters leading to the formation of $\mathrm{N}_{2} \mathrm{O}$ indicates that at low temperatures the presence of abundant NO surface species results in rapid recombination of $\mathrm{NO}$ and $\mathrm{N}$ surface species compared to $\mathrm{N}-\mathrm{N}$ adatoms, thus increasing the selectivity of $\mathrm{N}_{2} \mathrm{O}$. The reaction steps leading to the formation of nitrogen are influenced by the hydrogen concentration and temperature. The $\mathrm{N}_{2}$ selectivity exhibited a local maximum at an intermediate temperature $\left(100^{\circ} \mathrm{C}-200^{\circ} \mathrm{C}\right)$ which coincides with the progressive decrease in $\mathrm{N}_{2} \mathrm{O}$ selectivity, due to the increase in the rate of $\mathrm{NO}$ dissociation. The selectivity of the reaction towards $\mathrm{NH}_{3}$ gradually increases with subsequent hydrogenation of $\mathrm{N}$ adatom. This results in a shift of the product 
distribution to a mixture of $\mathrm{N}_{2}$ and $\mathrm{NH}_{3}$ as the temperature increases.
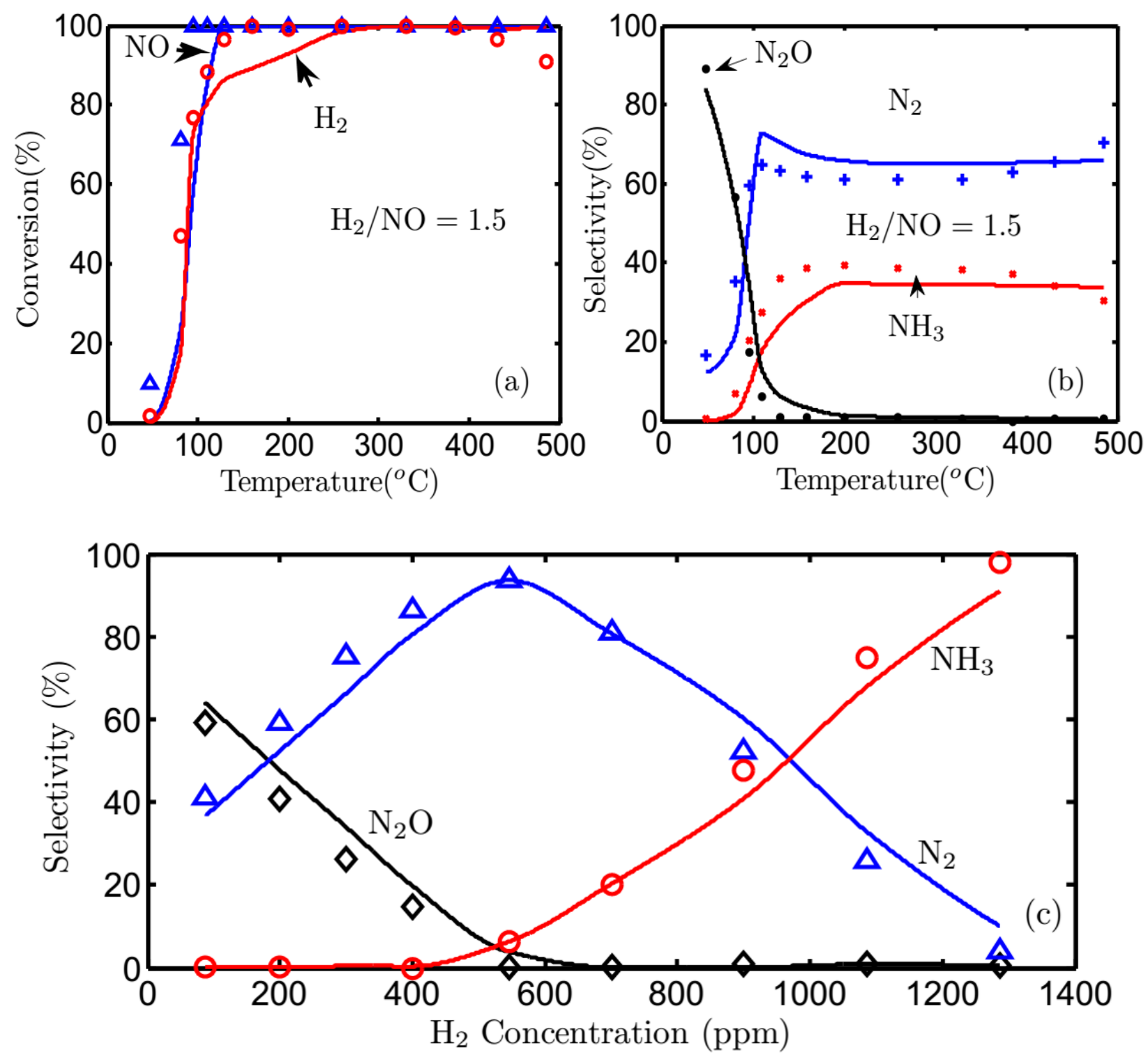

Figure 6: Model prediction results for $\mathrm{NO} / \mathrm{H}_{2}$ system (a) $\mathrm{NO}$ and $\mathrm{H}_{2}$ conversion for $\mathrm{H}_{2} / \mathrm{NO}$ $=1.5$ at different temperatures (Feed: 1000ppm NO, 1500ppm H $\mathrm{pH}_{2}, \mathrm{GHSV}=60,000 \mathrm{hr}^{-1}$ ), (b) Selectivities of $\mathrm{NH}_{3}, \mathrm{~N}_{2}, \mathrm{~N}_{2} \mathrm{O}$ for $\mathrm{H}_{2} / \mathrm{NO}=1.5$ at different temperatures, (c) Selectivities of $\mathrm{NH}_{3}, \mathrm{~N}_{2}, \mathrm{~N}_{2} \mathrm{O}$ for $\mathrm{T}=360^{\circ} \mathrm{C}$ at different inlet $\mathrm{H}_{2}$ concentrations (Feed: 500ppm NO, $\left.\mathrm{GHSV}=60,000 \mathrm{hr}^{-1}\right)$.

The overall reactions for the formation of $\mathrm{N}_{2}$ and $\mathrm{NH}_{3}$ are:

$$
\mathrm{NO}+\mathrm{H}_{2} \rightarrow 0.5 \mathrm{~N}_{2}+\mathrm{H}_{2} \mathrm{O} \quad \Delta \mathrm{H}=-332.1 \mathrm{~kJ} / \mathrm{mol}
$$




$$
\mathrm{NO}+2.5 \mathrm{H}_{2} \leftrightharpoons \mathrm{NH}_{3}+\mathrm{H}_{2} \mathrm{O} \quad \Delta \mathrm{H}=-378.3 \mathrm{~kJ} / \mathrm{mol}
$$

Formation of $\mathrm{NH}_{3}$ increases with $\mathrm{H}_{2} / \mathrm{NO}$ feed ratio and is consistent with the literature studies. Thus far the model reasonably predicts all the important steady state experimental observations, and since all the above mentioned surface phenomena are also present during transient operation, the model can also be applied for transient studies.

\section{$4.2 \quad \mathrm{NO} / \mathrm{CO}$ reaction system}

A much more complicated behavior occurs using $\mathrm{CO}$ as a reductant. $\mathrm{CO}$ is known to poison the Pt surface. Lorimer et. al. [42] have reported a negative order dependence of the $\mathrm{NO}$ reduction with $\mathrm{CO}$ on $\mathrm{Pt} / \mathrm{SiO}_{2}$ catalyst. The competitive adsorption of $\mathrm{CO}_{2}$ and $\mathrm{NO}_{2}$ during the NSR catalysis has been suggested previously [43]. During the reduction by CO or $\mathrm{C}_{3} \mathrm{H}_{6}$, it is likely that some carbonates form on the catalyst surface. It is well established that carbonates are more stable than hydroxides of barium [44], hence our model neglected the $\mathrm{Ba}(\mathrm{OH})_{2}$ formation. Of the other key parameters investigated the roles of the storage components and the reaction mechanism of carbonate formation are assessed. To reduce the complexity of the model due to the large number of possible reaction steps we assumed that equation $R 23$ represents the $\mathrm{CO}_{2}$ uptake. Figure 7 shows the overall $\mathrm{CO}$ and $\mathrm{NO}$ conversions on the $\mathrm{Pt} / \mathrm{Ba} / \mathrm{Al}_{2} \mathrm{O}_{3}$ catalyst at $270^{\circ} \mathrm{C}$ versus inlet $\mathrm{CO}$ concentration. The feed comprises 500 ppm NO and 15-1200 ppm CO as used in the experiments by Dasari et al. [45]. Initially, a steady increase in NO conversion is observed at low inlet CO concentrations, while the entire $\mathrm{CO}$ is converted to $\mathrm{CO}_{2}$. $\mathrm{NO}$ conversion attains a maximum at $\mathrm{CO}$ feed concentration of $\sim 300 \mathrm{ppm}$. As the $\mathrm{CO}$ concentration is further increased, its surface coverage increases thus inhibiting NO from adsorbing. NO conversion progressively declines to zero closely followed by $\mathrm{CO}$ conversion until the entire Pt surface is covered with CO species. Several schemes were proposed in the literature that describe $\mathrm{CO}$ conversion to $\mathrm{CO}_{2}$ and $\mathrm{NO}$ to $\mathrm{N}_{2} \mathrm{O}$ and $\mathrm{N}_{2}$. Granger et al. [46] studied the $\mathrm{NO} / \mathrm{CO}$ reaction on Pt catalysts using a Langmuir 
Hinshelwood model.

We consider a non-dissociative adsorption of $\mathrm{CO}$ and $\mathrm{NO}$ on the adsorption sites according to equations $R 1$ and $R 18$. The subsequent steps involve dissociation of adsorbed NO to form $\mathrm{N}$ and $\mathrm{O}$ adatoms. The selectivity of $\mathrm{N}_{2} / \mathrm{N}_{2} \mathrm{O}$ depends on the rate of recombination of $\mathrm{N}$ adatoms with $\mathrm{N}$ or $\mathrm{NO}$ on the surface. The difference in the reduction efficiency and the formation of NCO species on the catalyst surface suggest differing reduction mechanisms for $\mathrm{H}_{2}$ and $\mathrm{CO}$. However, it has been reported through FTIR investigations that the reduction occurs through Pt catalyzed pathway $[47,48]$. On Pt the two main reactions of NO and CO involves $\mathrm{N}_{2}$ and $\mathrm{N}_{2} \mathrm{O}$ formation according to:

$$
\begin{array}{ll}
2 \mathrm{NO}+\mathrm{CO} \rightarrow \mathrm{N}_{2} \mathrm{O}+\mathrm{CO}_{2} \quad \Delta H=-381.2 \mathrm{~kJ} / \mathrm{mol} \\
\mathrm{NO}+\mathrm{CO} \rightarrow 0.5 \mathrm{~N}_{2}+\mathrm{CO}_{2} & \Delta H=-373.3 \mathrm{~kJ} / \mathrm{mol}
\end{array}
$$

The presence of $\mathrm{H}_{2} \mathrm{O}$ in the feed renders the analysis of $\mathrm{NO} / \mathrm{CO}$ reaction slightly complicated due to the presence of surface species such as carboxylates, surface hydroxyl groups and $\mathrm{N}$ species. However, water is known to enhance the reduction of $\mathrm{NO}$ by $\mathrm{CO}$ and also results in the production of $\mathrm{NH}_{3}$. Two major pathways have been suggested as active in $\mathrm{NH}_{3}$ formation. One involves intermediate isocyanate species and the second involves the watergas shift reaction. From reaction steps $R 9-R 12$ and $R 18-R 20$ show that the water-gas shift is inherent in the kinetic model. To account for the isocyanate pathway we introduced reaction step $R 21$. Figure $7(\mathrm{~b})$ shows the impact of $\mathrm{H}_{2} \mathrm{O}$ on the conversions of $\mathrm{NO}$ and $\mathrm{CO}$ and that there is significant improvement in both conversions for $\mathrm{CO}$ feed concentration exceeding 300 ppm and containing $4 \% \mathrm{H}_{2} \mathrm{O}$. For $\mathrm{CO}$ concentration lower than $300 \mathrm{ppm}$, the difference in the conversion behavior is small, suggesting an interaction of adsorbed CO with $\mathrm{H}_{2} \mathrm{O} . \mathrm{H}_{2} \mathrm{O}$ is expected to clean the catalyst surface from adsorbed $\mathrm{CO}$ resulting in enhanced $\mathrm{NO}$ adsorption and subsequent reaction with $\mathrm{CO}$ and $\mathrm{H}$ surface species. 

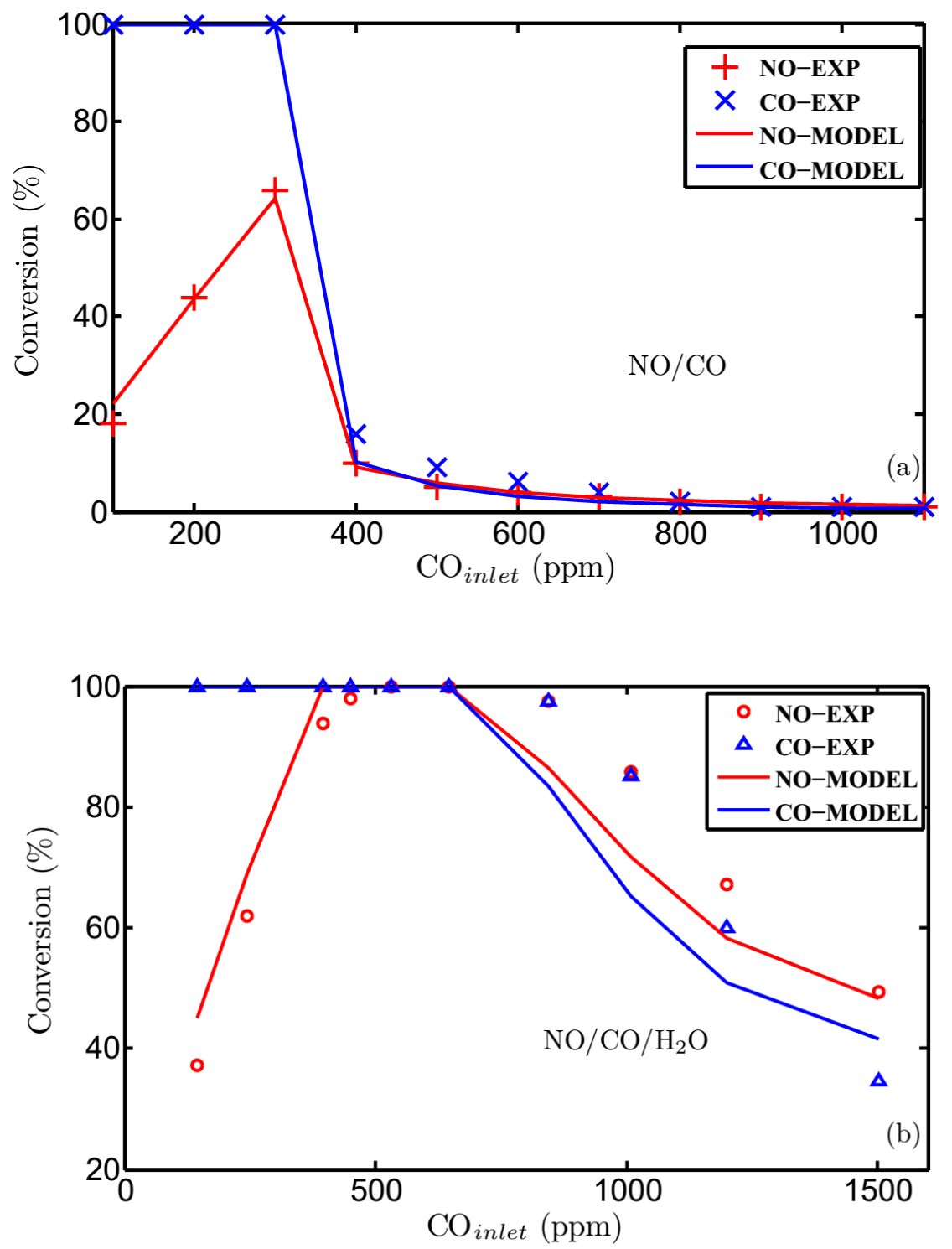

Figure 7: Effect of inlet $\mathrm{CO}$ concentration on the $\mathrm{NO}$ and $\mathrm{CO}$ conversion during the reaction of $\mathrm{NO}(500 \mathrm{ppm})+\mathrm{CO}(15-1200 \mathrm{ppm})$ and $\mathrm{NO}(500 \mathrm{ppm})+\mathrm{CO}(15-2500 \mathrm{ppm})+4 \%$ $\mathrm{H}_{2} \mathrm{O}$ at $270{ }^{\circ} \mathrm{C}$ over the $\mathrm{Pt} / \mathrm{BaO} / \mathrm{Al}_{2} \mathrm{O}_{3}$ catalyst.

\section{$4.3 \mathrm{NO} / \mathrm{C}_{3} \mathrm{H}_{6}$ reaction system}

Several investigations have been made to evaluate propylene as a $\mathrm{NO}_{x}$ reducing agent. The steady-state performance of the catalyst with respect to $\mathrm{NO} / \mathrm{C}_{3} \mathrm{H}_{6}$ system was examined by Kabin et al. [38] and their experimental results are used to evaluate the kinetic 


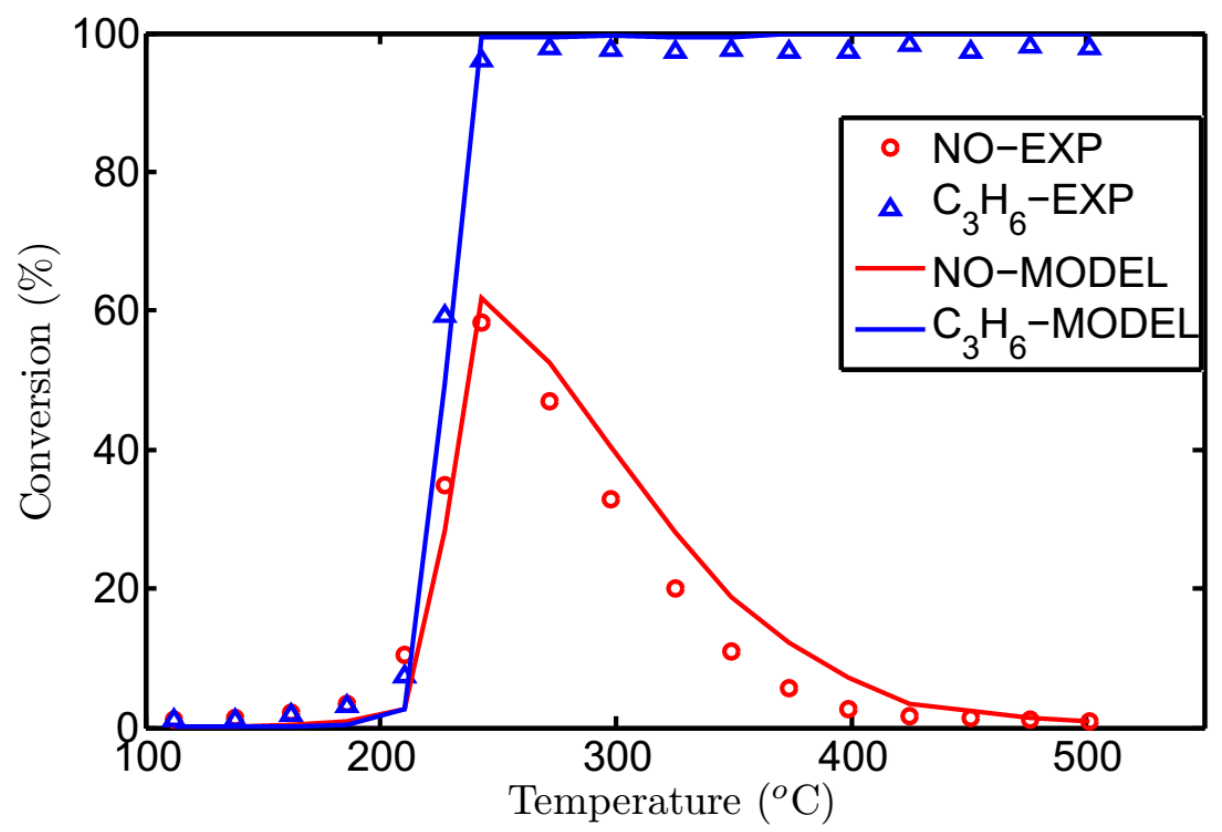

Figure 8: Steady-state $\mathrm{NO}_{x}$ conversion and $\mathrm{C}_{3} \mathrm{H}_{6}$ conversion vs. Feed Temperature during the reaction between 500 ppm NO, $5 \% \mathrm{O}_{2}, 1000 \mathrm{ppm}_{3} \mathrm{H}_{6}$.

modelproposed by equations $R 1-R 8$ and $R 18-R 22$. Figure 8 shows the $\mathrm{NO}_{x}$ conversion as a function of the feed temperature with a space velocity of $60,000 \mathrm{~h}^{-1}$, for a gas feed containing $500 \mathrm{ppm} \mathrm{NO}, 1000 \mathrm{ppm}_{3} \mathrm{H}_{6}$ and $5 \% \mathrm{O}_{2}$. The light off temperature is around $220^{\circ} \mathrm{C}$ which is close to that reported in the literature. The model gives a reasonably good prediction of both the $\mathrm{NO}$ and $\mathrm{C}_{3} \mathrm{H}_{6}$ conversions. At the lightoff the activation of propene is accompanied by the onset of $\mathrm{NO}$ reduction towards $\mathrm{N}_{2}$ and $\mathrm{N}_{2} \mathrm{O}$. $\mathrm{NO}_{x}$ conversion reaches a maximum of $60 \%$ around $\sim 250^{\circ} \mathrm{C}$ which is followed by a progressive decrease as the temperature is increased further. Kabin et al. have reported that the selectivity of $\mathrm{N}_{2}$ was low under low concentrations of propene, confirming the role of propene as a scavenger [40] removing the $\mathrm{O}$ adatoms formed by $\mathrm{NO}$ bond scission. It was also pointed out that in the presence of excess $\mathrm{O}_{2}$, the $\mathrm{O}$ adatoms produced from $\mathrm{NO}$ and $\mathrm{O}_{2}$ compete for the surface hydrocarbon species which as the temperature increases is dominated by the $\mathrm{O}_{2}$ dissociation. This increases the surface coverage by $\mathrm{O}$ adatom inhibiting the NO adsorption and thereby reducing the NO conversion. For the given concentrations of reactants the temperature rise 
could be as

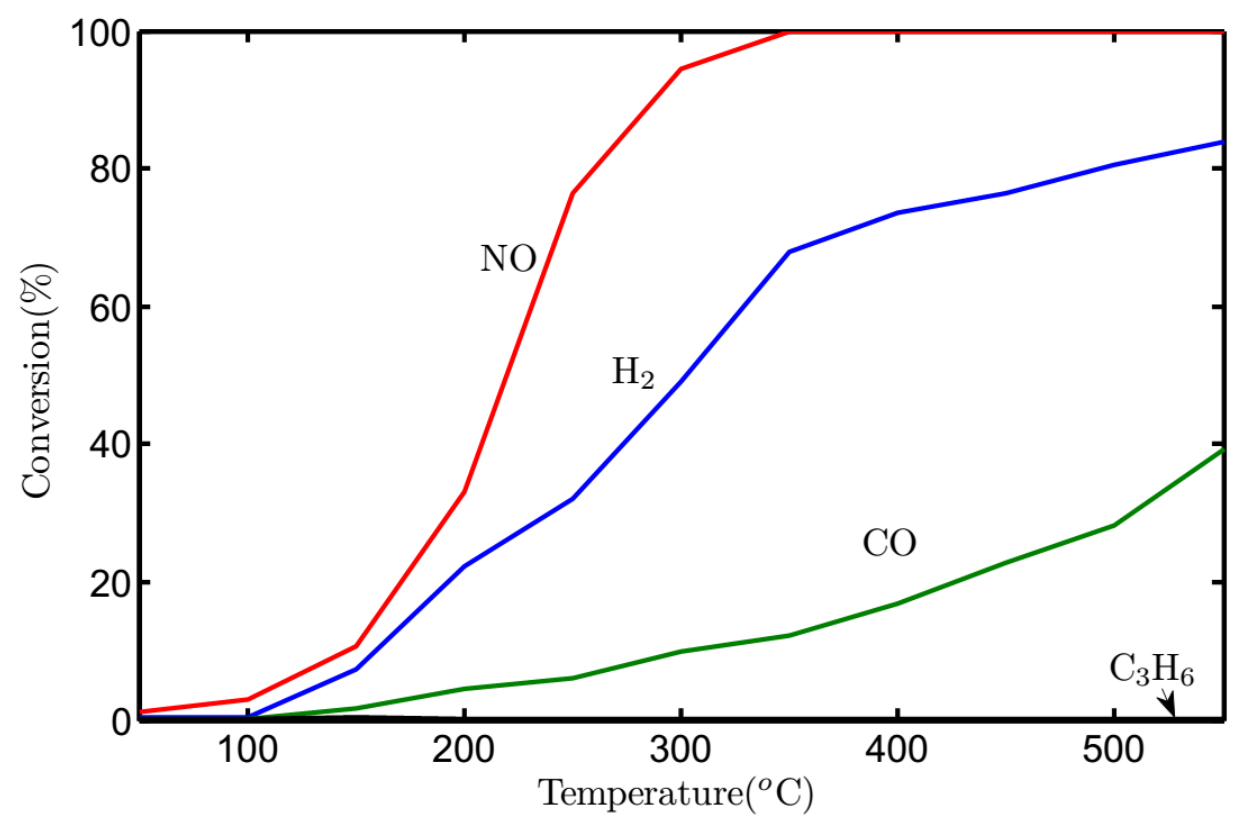

Figure 9: Model predictions of $\mathrm{NO}, \mathrm{H}_{2}, \mathrm{CO}$ and $\mathrm{C}_{3} \mathrm{H}_{6}$ conversions during steady state operation. 300ppm NO, $1 \% \mathrm{O}_{2}, 1 \% \mathrm{CO}, 0.33 \% \mathrm{H}_{2}, 0.33 \% \mathrm{C}_{3} \mathrm{H}_{6}$.

high as $60^{\circ} \mathrm{C}$ and is not negligible, on the grounds of simplicity in terms of calculations the present model doesn't account for the non-isothermal effects. Such analysis will be presented in future work.

\section{$4.4 \mathrm{NO} / \mathrm{H}_{2} / \mathrm{CO} / \mathrm{C}_{3} \mathrm{H}_{6}$ reaction system}

Real engine exhaust from the passenger vehicle is a mixture of various gas species as noted in the introduction. Consequently it is of practical importance to understand the behavior of $\mathrm{NO}_{x}$ storage and reduction process under the influence of such representative mixture $\left(\mathrm{H}_{2} / \mathrm{CO} / \mathrm{C}_{3} \mathrm{H}_{6}\right)$. Previous sections all described and reasonably captured the reduction performance of $\mathrm{NO}_{x}$ with individual species. Here, the co-existence of $\mathrm{H}_{2}, \mathrm{CO}, \mathrm{C}_{3} \mathrm{H}_{6}$ results in a complicated series of reactions and reaction networks occuring in the NSR catalyst and the micro-kinetic modeling approach adapted in this work qualitatively represents such complexity and validates the key assumptions made in developing the kinetic model. 

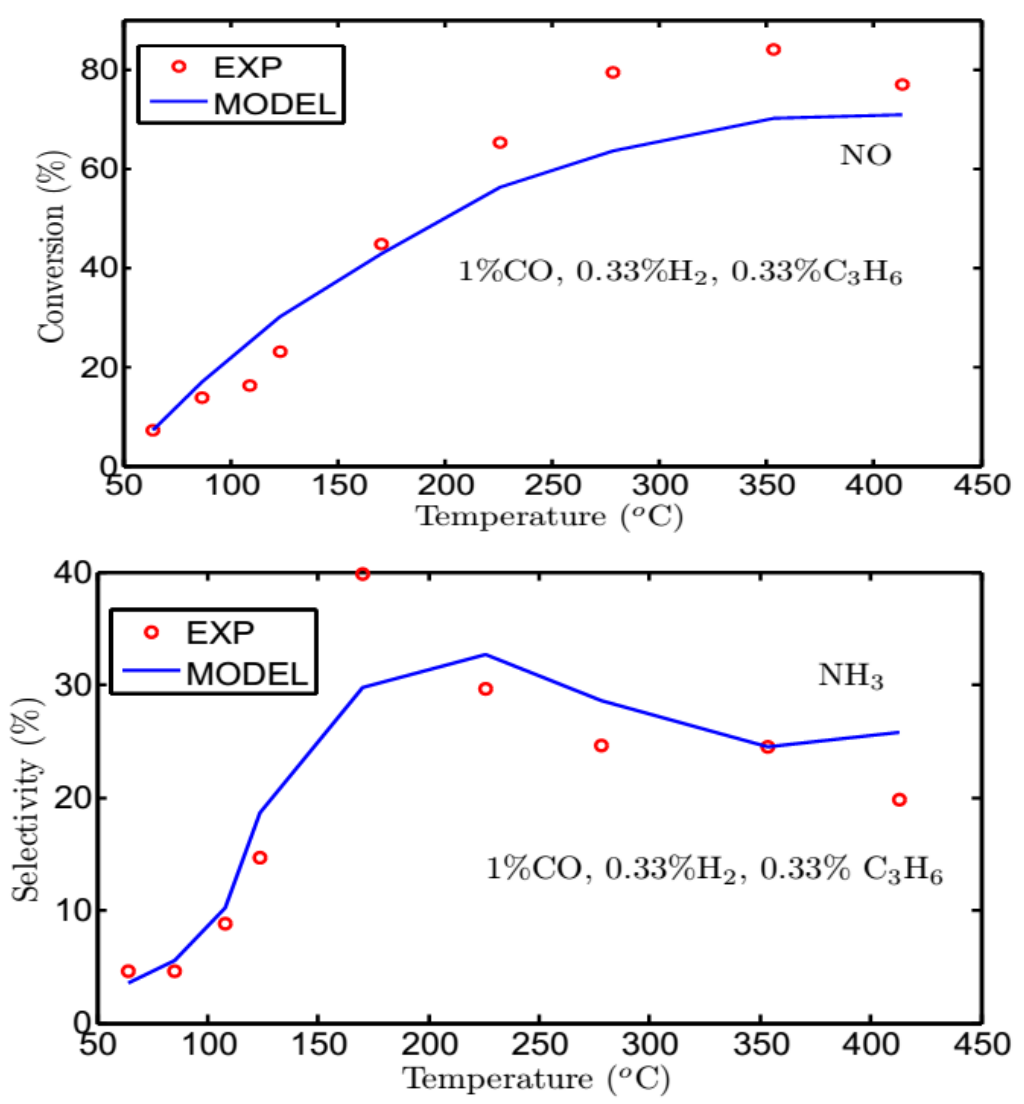

Figure 10: Model predictions of $\mathrm{NO}_{x}$ conversion and $\mathrm{NH}_{3}$ selectivities in the cyclic reduction operation. Lean: 300ppm NO, $8 \% \mathrm{O}_{2}$, 60s; Rich: $1 \% \mathrm{CO}, 0.33 \% \mathrm{H}_{2}, 0.33 \% \mathrm{C}_{3} \mathrm{H}_{6}, 1 \% \mathrm{O}_{2}$ for $5 \mathrm{~s}$.

Kinetic parameters estimated in the prior sections are used without any further tuning to calculate $\mathrm{NO}_{x}$ conversion in the presence of combned feed $\mathrm{H}_{2} / \mathrm{CO} / \mathrm{C}_{3} \mathrm{H}_{6}$. Figure 9 shows the conversions of $\mathrm{NO}_{x}, \mathrm{H}_{2}, \mathrm{CO}$ and $\mathrm{C}_{3} \mathrm{H}_{6}$ as a function of temperature. It can be observed that $\mathrm{H}_{2}$ conversion is significant while that of $\mathrm{CO}$ and $\mathrm{C}_{3} \mathrm{H}_{6}$ are negligible for the operation conditions considered.

As is known from prior studies, $\mathrm{H}_{2}$ is a more effective reductant than $\mathrm{CO}$ and $\mathrm{C}_{3} \mathrm{H}_{6}$. Similar behavior is predicted by the model as shown in Figure 9. However, it is to be noted that the conversion of propylene is negligible compared to $\mathrm{CO}$ and $\mathrm{H}_{2}$, this highlights the competition of reductant species to react with the surface $\mathrm{O}$ adatom. We also attempt to predict the cyclic studies performed by Wang et. al. [59] using a fully formulated NSR catalyst that 
contained ceria in addition to $\mathrm{BaO}$ as the storage material. The model predicts reasonably the $\mathrm{NO}_{x}$ conversion and selectivities of $\mathrm{NH}_{3}$ with the mixed feed containing $\mathrm{H}_{2} / \mathrm{CO} / \mathrm{C}_{3} \mathrm{H}_{6}$. However the comparison is made with the catalyst based on ceria/zirconia support, hence the model prediction is only a qualitative representation. Both the periods contain $5 \% \mathrm{CO}_{2}$ and $5 \% \mathrm{H}_{2} \mathrm{O}$; GHSV of $30000 \mathrm{hr}^{-1}$ and length of the catalyst $\left(\mathrm{Pt} / \mathrm{BaO} / \mathrm{CeO}_{2} / \mathrm{Zr} / \mathrm{Al}_{2} \mathrm{O}_{3}\right)$ is $7.5 \mathrm{~cm}[59]$.

\section{Conclusions}

The existing global kinetic models are unable to represent the feed composition dependency of the catalyst performance. We presented a detailed kinetic analysis of the $\mathrm{NO}_{x}$ storage and reduction on $\mathrm{Pt} / \mathrm{BaO} / \mathrm{Al}_{2} \mathrm{O}_{3}$ using $1+1$ dimensional two phase model accounting for washcoat diffusional limitations.

The isothermal model developed is able to satisfactorily predict $\mathrm{NO}_{x}$ conversions observed in the experimental studies and also predict the $\mathrm{N}_{2}$ and $\mathrm{NH}_{3}$ selectivities qualitatively. Performance of the catalyst in the presence of complex feed $\mathrm{H}_{2} / \mathrm{CO} / \mathrm{C}_{3} \mathrm{H}_{6}$ over a range of temperatures and inlet feed concentrations is evaluated under varying feed compositions. Prior experimental and computational evidence has shown the non-negligible impact of washcoat diffusion on deNO$_{x}$ efficiency of the monolith reactors which results in over predicting the $\mathrm{NO}_{x}$ conversion and inaccurately representing the scale-up performance. The kinetic scheme proposed in this work agrees with experimentally observed $\mathrm{CO}$ inhibition effects on $\mathrm{NO}_{x}$ conversion and is consistent with prior investigations performed by various groups. Complicated pathways suggested by experimental results are successfully captured by the model for example, water-gas shift and isocyanate pathways to form $\mathrm{NH}_{3}$ in the $\mathrm{NO} / \mathrm{CO}+\mathrm{H}_{2} \mathrm{O}$ system. The washcoat diffusion scheme incorporated into our model enabled an accurate representation of onboard and experimental conditions. The effect of diffusivities on the estimated parameters indicate that the true kinetics is dependent on the washcoat structure, nature 
and dispersion of the active materials.

\section{Acknowledgements}

This work was supported by the U.S. DOE National Energy Technology Laboratory (DE-EE0000205) and NSF-CBET grant \# 1258688. This report was prepared as an account of work sponsored by an agency of United States Government. Neither the United States Government nor any agency thereof, nor any of their employees, makes any warranty, express or implied, or assumes any legal liability or responsibility for the accuracy, completeness, or usefulness of any information, or process, disclosed. We would also like to thank and acknowledge the University of Houston IT Research Computing Center (RCC) for providing the necessary computing resources and their help.

\section{Notation}

$a=$ uncoated width/height of monolith channel (square)

$\mathrm{A}=$ pre-exponential factor (for units see Appendix )

$\mathrm{C}_{X}=$ total concentration of $\mathrm{X}$ sites $\left(\mathrm{X}=\mathrm{Pt}\right.$ or $\mathrm{BaO}$, mol of $\mathrm{BaO} / \mathrm{m}^{3}$ washcoat $)$

$\mathrm{C}_{\text {ref }}=$ reference concentration $\left(\mathrm{mol} / \mathrm{m}^{3}\right)$

$\mathrm{C}_{T m}=$ total concentration in fluid phase $\left(\mathrm{mol} / \mathrm{m}^{3}\right)$

$\mathrm{D}_{m, j}=$ diffusivity of species $j$ in gas phase $\left(\mathrm{m}^{2} / \mathrm{s}\right)$

$\mathrm{D}_{e o}=$ effective diffusivity at reference temperature

$\mathrm{D}_{e, w c}=$ effective diffusivity of species $j$ in washcoat $\left(\mathrm{m}^{2} / \mathrm{s}\right)$

$\mathrm{E}=$ activation energy $(k J / m o l)$

$\Delta H=$ heat of reaction

$\mathrm{k}_{c}(\mathrm{j}, \mathrm{z})=$ mass transfer coefficient of species $j$ at axial position ' $\mathrm{z}$ ' $(\mathrm{m} / \mathrm{s})$

$\mathrm{k}=$ reaction rate constant (for units refer to Appendices) 
$\mathrm{L}=$ length of the monolith $(\mathrm{m})$

$\mathrm{M}_{w j}=$ Molecular weight of species $j$

$\mathrm{OR}=$ overall reaction

$Q=$ heat of adsorption/desorption

$r_{e f f}=$ average pore radius

$\mathrm{R}_{v j}=$ rate of adsorption/desorption of species $j\left(\mathrm{~mol} / \mathrm{m}^{3}\right.$ washcoat $/ \mathrm{s}$ )

$\mathrm{R}_{l}=$ rate of reaction on the catalyst surface $\left(\mathrm{mol} / \mathrm{m}^{3}\right.$ washcoat $\left./ \mathrm{s}\right)$

$\mathrm{R}_{\Omega}=$ effective transverse length scale $(\mathrm{m})$

$\mathrm{t}=$ time $(\mathrm{s})$

$T=$ temperature $(\mathrm{K})$

$T_{r}=$ reference temperature $(\mathrm{K})$

$\bar{u}=$ average fluid velocity in the fluid phase $(\mathrm{m} / \mathrm{s})$

$\mathrm{X}_{j m}=$ cup mixing mole fraction of species $\mathrm{j}$

$\mathrm{X}_{j w c}=$ mole fraction of species $\mathrm{j}$ in washcoat

$\mathrm{z}=$ axial coordinate $(\mathrm{m})$

\section{Greek Letters}

$\alpha_{v}=$ platinum surface area per unit washcoat volume $\left(\mathrm{m}^{2} / \mathrm{m}^{3}\right)$

$\delta_{w c}=$ washcoat thickness $(\mathrm{m})$

$\varepsilon_{w c}=$ porosity of washcoat

$\theta_{j}=$ fractional coverage of surface species on the catalyst surface

$v_{j r}=$ stoichiometric coefficient of surface species $j$ in reaction $r$

\section{References}

[1] T Kobayashi, T Yamada, K Kayano, SAE Tech. Pap. Ser. 97-07-45 (1997)

[2] E Fridell, H Persson, B Westerberg, L Olsson, M Skoglundh, Catal. Letters 66 (2000) $71-74$ 
[3] S Salasc, M Skoglundh, E Fridell, Appl. Catal. B: Environ 36 (2002) 145-160

[4] A Amberntsson, H Persson, P Engstrom, B Kasemo, Appl. Catal. B: Environ 31 (2001) 27

[5] A Lindholm, N W Currier, E Fridell, A Yezerets, L Olsson, Appl. Catal. B: Environ 75 (2007) $78-87$

[6] T J Toops, D B Smith, W S Epling, J E Parks, W P Partridge, Appl. Catal. B: Environ $58(\mathbf{2 0 0 5}) 255$

[7] W S Epling, L E Campbell, J E Parks, Catal. Letters 90 (2003) 45

[8] N W Cant, M J Patterson, Catal. Letters 85 (2003) 153.

[9] J Hepburn, E Thanasiu, D Dobson,W Watkins, SAE Tech. Pap. No. 962051 (1996)

[10] L Olsson, R J Blint, E Fridell, Ind. Engg. Chem. Res. 44 (2005) 3021-3032

[11] U Tuttlies, V Schmeisser, G Eigenberger, Top. in Catal. 30/31 (2004) 187-192

[12] C M L Scholz, V R Gangwal, J H B J Hoebink, J C Schouten, Appl. Catal. B: Environ 70 (2007) $226-232$

[13] D Bhatia, R W McCabe, M P Harold, V Balakotaiah, J. of Catalysis 266 (2009) 106119

[14] D Bhatia, R D Clayton, M P Harold, V Balakotaiah , Catal. Today 147S (2009) S250S256

[15] L Olsson, H Persson, E Fridell, M Skoglundh, B Andersson, J. Phys. Chem. B 105 (2001) 6895-6906

[16] K Ramanathan, V Balakotaiah, Chem. Engg. Sci. 58 (2003) 1381

[17] H Mahzoul, J F Brilhac, P Gilot, Appl. Catal. B: Environ 20 (1999) 47-55. 
[18] W S Epling, J E Parks, G C Campbell, A Yezerets, N W Currier, L E Campbell, Catal. Today 96 (2004) 21-30.

[19] F Prinetto, G Ghiotti, I Nova, L Lietti, E Tronconi, P Forzatti, J. Phys. Chem. B 105 (2001) 12732-12745.

[20] A Lindholm, N W Currier, J Li, A Yezerets, L Olsson, J. of Catalysis 258 (2008) $273-288$.

[21] J Xu, R Clayton, V Balakotaiah, M P Harold, Appl. Catal. B: Environ. 77 (2008) $395-408$

[22] V. Medhekar, V. Balakotaiah, M. P. Harold, Catal. Today 121 (2007) 226-236

[23] K S Kabin, P Khanna, R L Muncrief, V Medhekar, M P Harold, Catal. Today 114 (2006) 72 .

[24] E Fridell, M Skoglundh, B Westerberg, S Johansson, G Smedler, J. of Catalysis 183 (1999) 196.

[25] S S Chaugule, A Yezerets, N W Currier, F H Ribeiro, W N Delgass, Catal. Today 151 (2010) 291-303

[26] A Kumar, M P Harold, V Balakotaiah, J. of Catalysis 270 (2010) 214-223.

[27] S Poulston, R R Rajaram, Catal. Today 81 (2003) 603-610.

[28] Z Liu, J A Andersson, J. of Catalysis 224 (2004) 18-27.

[29] P Jozsa, E Jobson, M Larsson, Top. in Catal. 30-31 (2004) 177-180.

[30] H Abdulhamid, E Fridell, M Skoglundh, Top. in Catal. 30-31 (2004) 161-168.

[31] R D Clayton, Ph.D Dissertation, University of Houston (2008). 
[32] L Olsson, M Abul-Milh, H Karlsson, E Jobson, P Thormahlen, A Hinz, Top. in Catal. 30-31 (2004) 85-90

[33] A Luengnaruemitchai, S Osuwan, E Gulari, Catal. Communications 4 (2003) 215-221

[34] T Lesage, C Terrier, P Bazin, J Saussey, M Daturi, Phys. Chem. Chem. Phys. 5 (2003) 4435

[35] I Nova, L Lietti, P Forzatti, F Frola, F Prinetto, G Ghiotti, Top. in Catal. 52 (2009) 1767

[36] T Szailer, J H Kwak, D H Kim, J C Hanson, C H F Peden, J Szanyi, J. of Catalysis 239 (2006) $51-64$

[37] M L Unland, J. of Phys. Chem. 77 (1973) 1952

[38] K S Kabin, R L Muncrief, M P Harold, Catal. Today 96 (2004) 79-89

[39] P T Boggs, J R Donaldson, R H Byrd, R B Schnabel, ACM Trans. Math. Soft 15 (1989) 348-364

[40] A Kotsifa, D I Kondarides, X E Verikios, Appl. Catal. B: Environ 80 (2008) 260-270.

[41] D James, E Fourre, M Ishii, M Bowker, Appl. Catal. B: Environ 45 (2003) 147-159.

[42] D Lorimer, A T Bell, J. of Catalysis 59 (1979) 223

[43] F Rodrigues, L Juste, C Potvin, J F Tempè, G Blanchard, G Djéga-Mariadasson, Catal. Letters $72(\mathbf{2 0 0 1}) 59$

[44] L Lietti, P Forzatti, I Nova, E Tronconi, J. of Catalysis 204 (2001) 175-191

[45] P R Dasari, R Muncrief, M P Harold, Catal. Today 184 (2012) 43-53

[46] P Granger, C Dathy, J J Lecomte, L Leclercq, M Prigent, G Mabilon, G Leclercq, J. of Catalysis 173 (1998) 304-314 
[47] P Forzatti, L Lietti, I Nova, S Morandi, F Prinetto, G Ghiotti, J. of Catalysis 274 (2010) 163-175

[48] S Morandi, G Ghiotti, L Castoldi, L Lietti, I Nova, P Forzatti, Catal. Today 176 (2011) 399-403

[49] I Nova, L Lietti, P Forzatti, F Prinetto, G Ghiotti, Catal. Today 151 (2010) 330-337.

[50] M E Bartram, R G Windham, B E Koel, Surf. Science 184 (1987) 57-74

[51] P Granger, V I Parvulescu, Chem. Reviews 111 (2011) 3155-3207

[52] B deB Darwent, Nat. Stand. Ref. Data Series 31 (1970) 1-52

[53] R C Weast, CRC Handbook of Chemistry and Physics, CRC Press, FL (1991)

[54] F Gobal, S Azizian, Langmuir 13 (1997) 5999-6000

[55] K Christmann, Surf. Sci. Reports 9 (1988) 1-163

[56] W R Williams, C M Marks, L D Schmidt, J. of Phys. Chem. 96 (1992) 5922-5931

[57] J Segner, C T Campbell, G Doyen, G Ertl, Surf. Science 138 (1984) 505-523

[58] H Steininger, S Lehwald, H Ibach, Surf. Science 123 (1982) 264-282

[59] J Wang, Y Ji, Z He, M Crocker, M Dearth, R W McCabe, App. Catal. B: Environ 111-112 (2012) 562-570 


\section{Appendix}

\section{A1: Constant parameters}

$\begin{array}{ll}\text { Parameter } & \text { Value } \\ a & 1.1 \mathrm{~mm} \\ R_{\Omega} & 261 \mu \mathrm{m} \\ L & 2 \mathrm{~cm} \\ S h_{e 0} & 3.608 \\ \alpha_{v} & 1.5 \times 10^{6} \mathrm{~m}^{2} \mathrm{Pt} / \mathrm{m}^{3} \text { washcoat } \\ \delta_{w c} & 30 \mu \mathrm{m} \\ \epsilon_{w c} & 0.4 \\ C_{P t} & 8 \mathrm{~mol} / \mathrm{m}^{3} \\ C_{B a O}(f), C_{B a O}(s) & 66.2,272 \mathrm{~mol} / \mathrm{m}^{3}\end{array}$




\section{A2: Temperature dependent parameters}

$\begin{array}{ll}\text { Parameter } & \text { Value/Expression } \\ \bar{u} & u_{\text {ref }}\left(\frac{T}{T_{\text {ref }}}\right) ; u_{\text {ref }}=1 \mathrm{~m} / \mathrm{s}, T_{\text {ref }}=548.15^{\circ} \mathrm{K}\left(275^{\circ} \mathrm{C}\right) \\ C_{T m} & P_{\text {atm }} / R T\left(\mathrm{~mol} / \mathrm{m}^{3}\right) \\ D_{m, N O} & 1.33 \times 10^{-9}(T)^{1.696} \\ D_{m, N O_{2}} & 1.03 \times 10^{-9}(T)^{1.682} \\ D_{m, O_{2}} & 0.8 \times 10^{-9} \times T^{1.7037} \\ D_{m, N_{2} O} & 0.81 \times 10^{-9}(T)^{1.690} \\ D_{m, N_{2}} & 1.34 \times 10^{-9}(T)^{1.690} \\ D_{m, N H_{3}} & 1.22 \times 10^{-9}(T)^{1.739} \\ D_{m, H_{2}} & 5.8 \times 10^{-9}(T)^{1.666} \\ D_{m, H_{2} O} & 0.95 \times 10^{-9}(T)^{1.778} \\ D_{m, C O} & 1.35 \times 10^{-9}(T)^{1.701} \\ D_{m, C O_{2}} & 0.89 \times 10^{-9}(T)^{1.686} \\ D_{m, C_{3} H_{6}} & 1.35 \times 10^{-9}(T)^{1.695}\end{array}$

\section{A3: Catalyst properties}

$\begin{array}{lllll}\text { Catalyst Composition } & \text { Pt }(w t \%) & \mathrm{BaO}(w t \%) & \text { Pt Dispersion(\%) } & \text { Pt Area }\left(\mathrm{m}^{2} / g\right) \\ \mathrm{Pt} / \mathrm{BaO} / \mathrm{Al}_{2} \mathrm{O}_{3} & 2.2 & 16.3 & 21.9 & 1.19\end{array}$




\section{A4: Surface energetics}

\begin{tabular}{|c|c|c|c|c|c|}
\hline Reaction & $\Delta H_{g}(k J / m o l)$ & $Q_{1}(k J / m o l)$ & $Q_{2}(k J / m o l)$ & $Q_{3}(k J / m o l)$ & $\Delta H_{s}(k J / m o l)$ \\
\hline$N O * \rightarrow N *+O *$ & $634.2[53]$ & $109[51]$ & $487.2[54]$ & $357.2[54]$ & -100.8 \\
\hline $\mathrm{NO}_{2} * \rightarrow \mathrm{NO} *+\mathrm{O} *$ & $306[52]$ & $80[50]$ & 109 & 357.2 & -80 \\
\hline$O H * \rightarrow O *+H *$ & $428[52]$ & $201[56]$ & 357.2 & $254[55]$ & 18 \\
\hline $\mathrm{H}_{2} \mathrm{O} * \rightarrow O H *+H *$ & $498[52]$ & $45[56]$ & 201 & 254 & 88 \\
\hline$O_{2} \rightarrow 2 O *$ & $498[52]$ & - & 357.2 & 357.2 & -216.4 \\
\hline$H_{2} \rightarrow 2 H *$ & $436[52]$ & - & 254 & 254 & -72 \\
\hline$N_{2} \longleftarrow 2 N *$ & $945.4[52]$ & - & 487.2 & 487.2 & 29 \\
\hline$N_{2} O \leftarrow N O *+N *$ & $481[52]$ & - & 109 & 487.2 & 115 \\
\hline $\mathrm{CO}_{2} * \rightarrow \mathrm{CO} *+\mathrm{O} *$ & $532[52]$ & $20[57]$ & $134[58]$ & 357 & 61 \\
\hline
\end{tabular}




\section{A5: Rate expressions and kinetic constants}

Rate Expression

$R 1: k_{1 f} X_{N O} \theta_{v}-k_{1 r} \theta_{N O}$

$R 2: k_{2 f} \theta_{N O} \theta_{v}-k_{2 r} \theta_{N} \theta_{O}$

$R 3: k_{3 f} \theta_{\mathrm{NO}} \theta_{\mathrm{O}}-k_{3 r} \theta_{\mathrm{NO}_{2}}$

$R 4: k_{4 f} \theta_{\mathrm{NO}_{2}}-k_{4 r} X_{\mathrm{NO}_{2}} \theta_{v}$

$R 5: k_{5 f} X_{O_{2}} \theta_{v}-k_{5 r} \theta_{O}^{2}$

$R 6: k_{6 f} \theta_{N}^{2}$

$R 7: k_{7 f} \theta_{N O} \theta_{N}$

$R 8: k_{8 f} \theta_{\mathrm{BaO}} \theta_{\mathrm{NO}_{2}}-k_{8 r} \theta_{v} \theta_{\left.\mathrm{Ba}_{(\mathrm{NO}}\right)_{2}}(f)$

$R 8: k_{8 f} \theta_{\mathrm{BaO}} \theta_{\mathrm{NO}_{2}}-k_{8 r} \theta_{v} \theta_{\mathrm{Ba}\left(\mathrm{NO}_{3}\right)_{2}}(s)$

$R 9: k_{9 f} X_{H_{2}} \theta_{v}-k_{9 r} \theta_{H}^{2}$

$R 10: k_{10 f} \theta_{H} \theta_{O}-k_{10 r} \theta_{O H}$

$R 11: k_{11 f} \theta_{O H} \theta_{H}-k_{11 r} \theta_{H_{2} O}$

$R 12: k_{12 f} \theta_{\mathrm{H}_{2} \mathrm{O}}-k_{12 r} X_{\mathrm{H}_{2} \mathrm{O}} \theta_{v}$

$R 13: k_{13 f} \theta_{N O} \theta_{H}-k_{13 r} \theta_{N} \theta_{O H}$

$R 14: k_{14 f} \theta_{N} \theta_{H}-k_{14 r} \theta_{N H} \theta_{v}$

$R 15: k_{15 f} \theta_{N H} \theta_{H}-k_{15 r} \theta_{v} \theta_{N H_{2}}$

$R 16: k_{16 f} \theta_{N H_{2}} \theta_{H}-k_{16 r} \theta_{N H_{3}} \theta_{v}$

$R 17: k_{17 f} \theta_{\mathrm{NH}_{3}}-k_{17 r} \mathrm{X}_{\mathrm{NH}_{3}} \theta_{v}$

$R 18: k_{18 f} X_{C O} \theta_{v}-k_{18 r} \theta_{C O}$

$R 19: k_{19 f} \theta_{C O} \theta_{O}-k_{19 r} \theta_{C O_{2}} \theta_{v}$

$R 20: k_{20 f} \theta_{\mathrm{CO}_{2}}-k_{20 r} X_{\mathrm{CO}_{2}} \theta_{v}$

$R 21: k_{21 f} \theta_{C O} \theta_{N}-k_{21 r} \theta_{N C O} \theta_{v}$

$R 22: k_{22 f} \theta_{\mathrm{NCO}} \theta_{\mathrm{H}_{2} \mathrm{O}}-k_{22 r} \theta_{\mathrm{NH}_{2}} \theta_{\mathrm{CO}_{2}}$

$R 23: k_{23 f} \theta_{\mathrm{BaO}} \theta_{\mathrm{CO}_{2}}-k_{23 r} \theta_{v} \theta_{\mathrm{BaCO}_{3}}(f)$

$R 23: k_{23 f} \theta_{\mathrm{BaO}} \theta_{\mathrm{CO}_{2}}-k_{23 r} \theta_{v} \theta_{\mathrm{BaCO}_{3}}(s)$
$A_{f}\left(\mathrm{~mol} / \mathrm{m}^{3} / \mathrm{s}\right) / S_{0} A_{r}\left(\mathrm{~mol} / \mathrm{m}^{3} / \mathrm{s}\right) / S_{0} E_{f}(k J / \mathrm{mol}) \quad E_{r}(k J / m o l)$

0.85

$2.5 \times 10^{16}$

109

$3 \times 10^{11}$

$4 \times 10^{13}$

63

163

$4 \times 10^{8}$

$2.5 \times 10^{13}$

80.5

1.0

80.1

0.07

$4 \times 10^{14}$

$1 \times 10^{12}$

$7 \times 10^{12}$

$2 \times 10^{12}$

$2 \times 10^{11}$

0.046

$4 \times 10^{12}$

$1 \times 10^{13}$

$3 \times 10^{13}$

$4 \times 10^{13}$

$2 \times 10^{13}$

$4 \times 10^{12}$

$4 \times 10^{12}$

$2 \times 10^{13}$

1.0

$6 \times 10^{11}$

$9 \times 10^{10}$

$4 \times 10^{12}$

$4 \times 10^{14}$

$5 \times 10^{10}$

$5 \times 10^{8}$
$-$

$-$

$5 \times 10^{13}$

$2 \times 10^{12}$

$4 \times 10^{11}$

$6.28 \times 10^{13}$

$4 \times 10^{13}$

0.3

$4 \times 10^{11}$

$2 \times 10^{12}$

$4 \times 10^{12}$

$2 \times 10^{12}$

0.73

$1.6 \times 10^{13}$

$4 \times 10^{12}$

0.5

$4 \times 10^{14}$

$2 \times 10^{13}$

$2 \times 10^{12}$
$4 \times 10^{14}$
$-$

60

72.2

62

81

$-$

73.5

22.4

45

62

112

61.3

74.2

51

$-$

68

20

85

72

47

80
134

129

120

110

307

160

214

$-$

$-$

210

230

72

91

110

180

70.6

90

60
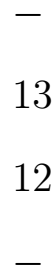

340 

$R 24: k_{24 f} X_{C_{3} H_{6}} \theta_{v}-k_{24 r} \theta_{C H_{2}}$
0.3
$4 \times 10^{12}$
105
$R 25: k_{25 f} \theta_{\mathrm{CH}_{2}} \theta_{\mathrm{O}}-k_{25 r} \theta_{C O} \theta_{\mathrm{H}_{2} \mathrm{O}}$
$4 \times 10^{13}$
$4 \times 10^{12}$
90
380 